\title{
LOS VENCEDORES VENCIDOS: LA PECULIAR MEMORIA DE LA DIVISIÓN AZUL, 1945-2005
}

El 12 de octubre de 2004, el desfile militar que por el centro de Madrid conmemoraba el Día de la Hispanidad estuvo protagonizado por un hecho insólito. Junto a las altas autoridades civiles y militares del Estado, compartían tribuna un representante de los combatientes republicanos españoles de la famosa 9. ${ }^{2}$ compañía de la División Leclerc durante la II Guerra Mundial, Luis Royo... y un representante de la Fundación División Azul: el antiguo combatiente franquista de la guerra civil, posterior voluntario en el frente ruso con el grado de sargento y prisionero en la URSS entre 1943 y 1954, Ángel Salamanca. La polémica anidó en los medios de comunicación durante semanas. Pero aún más sorprendente fue la justificación ofrecida por el ministro de Defensa, que apelaba a la reconciliación y a la superación de las heridas del pasado como justificación para invitar a ex-combatientes de los dos bandos enfrentados en 1936-39, arguyendo que ambos habían luchado por España. Argumento que fue admitido por varios columnistas ${ }^{1}$. Fuera de los partidos situados a la izquierda del PSOE y los partidos nacionalistas subestatales, el tratamiento dado a esa presencia en los medios de comunicación españoles fue relativamente benigno ${ }^{2}$.

Este hecho, sorprendente a primera vista, se explica en buena parte porque la División Azul, su recuerdo y su memoria, no sólo goza de un marchamo heroico y exótico que le confieren un lugar especial en las guerras españolas del siglo XX. También disfruta de una memoria peculiar, en muchos aspectos benigna, forjada desde antes incluso del final de la II Guerra Mundial. En este artículo intentaremos acercarnos brevemente a ella a través del elemento constructor principal, aunque no único, que ha configurado lo que podemos denominar el relato divisionario: la abundante producción autobiográfica y/o

1. Por ejemplo, vid. Carreras, Francesc de, «Agobiados por los símbolos», La Vanguardia, 16.10.2004, p. 8.

2. Por ejemplo, vid. las reacciones de El País, 11.10 y 13.10 .2004 , p. 8. 
ficcional con elementos autobiográficos de los veteranos de guerra y por sus asociaciones.

\section{1. ¡RUSIA ES CULPABLE!}

El 24 de junio de 1941, dos días después de que el III Reich invadiese la Unión Soviética, una manifestación de miembros y simpatizantes de FET de las JONS transcurrió por el centro de Madrid. Ramón Serrano Súñer arengó a los manifestantes desde un balcón de la sede de FET en Madrid, con una conocida frase: «Rusia es culpable. De nuestra Guerra Civil, de la muerte de José Antonio". Los españoles debían participar al lado de Alemania en una empresa que se suponía rápida, de la mano de un ejército invencible llamado a imponer el Nuevo Orden en Europa, para garantizar la presencia relevante de España en ese nuevo orden. Y la participación en la campaña rusa era vista como una continuación de la Guerra Civil: la lucha contra el comunismo, iniciada por los falangistas y sus aliados en julio de 1936, y de la que los españoles habrían sido pioneros en la victoria, continuaría ahora hasta el mismo corazón del Imperio del Mal.

Entre principios de julio de 1941, cuando parte la primera expedición compuesta por unos 18.000 voluntarios, y principios de febrero de 1944, alrededor de 45.000 combatientes españoles pasaron por la llamada «División Española de Voluntarios», "250 (spanische) Division» o, más comúnmente, "División Azul". De ellos, alrededor de 4.300 no volvieron, y cerca de un $40 \%$ adicional sufrieron heridas de diversa consideración, de las que en numerosos casos arrastraron secuelas de por vida. Además, un número indeterminado de voluntarios españoles, entre 300 y 700, se enrolaron desde febrero de 1944 en diversas compañías de la Wehrmacht y las Waffen SS. Alrededor de 484 combatientes españoles fueron hechos prisioneros por el Ejército Rojo. De ellos retornaron a España un total de 248 a primeros de abril de 1954, completados posteriormente con una pequeña expedición de 47 repatriados en mayo de $1959^{3}$.

No fue una rápida y gloriosa campaña, como los voluntarios del verano de 1941 esperaban. Pero, pese a ello, la experiencia de la División Azul [DA] fue decisiva para el fascismo español. De ella participó, de entrada, una buena parte de la militancia falangista más radical. Es decir, aquellos que optaban decididamente por un alineamiento sin fisuras del régimen de Franco con las potencias del Eje, y que asimismo preconizaban una imprecisa «revolución social

\footnotetext{
3. Sobre la División Azul existe una amplia bibliografía, centrada en los aspectos diplomáticos y militares. Vid. Proctor, Raymond, Agonía de un neutral: Las relaciones hispanoalemanas durante la segunda guerra mundial y la División Azul, Madrid, 1972; KLeINFELD, Gerald R., y TAmBs, Lewis A., La División Española de Hitler. La División Azul en Rusia, Madrid, 1983 [1979]; RuHz, Klaus-Jörg, Franco, Falange y III Reich. España durante la II Guerra Mundial, Madrid, 1986 [1975]; Bowen, Wayne, Spaniards and Nazi Germany: Collaboration in the New Order, Columbia, 2000; MORENo Jullá, Xavier, La División Azul. Sangre española en Rusia, 1941-1945, Barcelona, 2004, y los capítulos correspondientes de ESTES, Kenneth William, A European Anabasis-Western European Volunteers in the German Army and SS, 1940-1945, s. 1., 2003 (disponible en: www.gutenberg-e.org/esk01/main.html).
} 
y nacional» que fuese más allá de los pactos con la Iglesia y la derecha católica tradicional española. Fueron, sobre todo, veteranos falangistas de camisa vieja, muchos de ellos ex-combatientes de la Guerra Civil o que habían pasado los tres años de conflicto en la zona republicana. Pero también jóvenes estudiantes falangistas, o que no habían participado en la Guerra Civil por haber vivido en zona republicana hasta el final de la guerra, en bastantes casos con cuentas familiares pendientes con el comunismo por haber perdido familiares a manos de la represión en zona republicana. La participación en la DA era contemplada, así, como una venganza, una aventura y una inversión: en Rusia adquirirían una influencia y prestigio que les permitiría volver a casa e imponer el fascismo "revolucionario" sin concesiones.

Sin embargo, la dura realidad del invierno ruso, de la brutalización de la guerra que tuvo lugar de modo drástico en el Frente del Este ${ }^{4}$, de la tenaz resistencia soviética y la constatación del estancamiento, primero, y el retroceso después del Ejército alemán y sus aliados (el "ejército europeo frente al bolchevismo») se sumó a su vuelta a España, tras 1943, a la constatación del hecho de que el régimen franquista evitó el compromiso decidido con el III Reich y buscó un acercamiento a los Aliados. Ello fue visto como una "traición" por parte de los divisionarios, pero al mismo uiempo la DA fue presentada en lo sucesivo como una avanzada de la lucha de la civilización occidental frente al comunismo.

La memoria de la DA, su recuerdo a través de la celebración de actos públicos, la erección de lugares de memoria y los nomenclátores urbanos, no fue totalmente silenciada o prohibida por el régimen franquista, pese a tratarse de la prueba más palpable de su cercanía ideológica a las potencias del Eje durante la II Guerra Mundial. Pero sí fue convenientemente mantenida bajo control, y en momentos concretos reutilizada adecuadamente por el régimen, dándole nuevos significados acordes con las necesidades geoestratégicas de la coyuntura. En contraste con los apoyos oficiales de que gozaron la Hermandad Nacional de Ex-Combatientes o la Hermandad Nacional de Alféreces Provisionales, auténticos «agentes transmisores» y cultivadores de la memoria oficial del bando vencedor en $1939^{5}$, y creadas junto a otras varias entidades entre mediados y finales de la década de 1950, en parte como reacción de los sectores puristas del franquismo frente a la apertura hacia Occidente protagonizada por el régimen, las Hermandades de la División Azul gozaron en un principio de un apoyo oficial más bien tibio por parte del régimen de Franco. Pese a ello, mantuvieron una estrecha relación con el resto de asociaciones de veteranos ${ }^{6}$.

4. Vid. BARTOV, Omer, The Eastern Front, 1941-45, German Troops and the Barbarisation of Warfare, Houndmills / Nueva York, 2001 [1985].

5. Vid. Aguilar, Paloma, "Agents of Memory: Spanish Civil War veterans and disabled soldiers", en WinTER, Jay y Sivan, Emmanuel (eds.), War and Remembrance in the Twentieth Century, New York, Cambridge UP, 1999, pp. 84-103.

6. Vid. Rodrícuez Jiménez, José Luis, La extrema derecha española en el siglo XX, Madrid, 1997, pp. 361-64. En 1974, según recoge este autor (p. 396), la Hermandad de la DA habría llegado a agrupar a unos 12.550 ex-combatientes de la División, lo que supone alrededor de un tercio de los supervivientes. 
La actividad publicística, y en menor medida editorial, de las Hermandades de la DA ha sido notable en su más de medio siglo de existencia, aunque sujeta a diversos altibajos, patentes en la irregularidad y modestia de buena parte de sus publicaciones periódicas ${ }^{7}$. Un porcentaje importante de los libros de memorias y de las novelas cuyo tema central era la experiencia de la División Azul fue publicada en editoriales claramente vinculadas a los círculos más radicales de la Falange. He ahí el caso de Caralt o Acervo, propiedad respectivamente del falangista y concejal del Ayuntamiento de Barcelona, Luis de Caralt, y del veterano de la DA, José Llorens Borrás, muy vinculado a exiliados fascistas europeos (como, por ejemplo, el rumano Horia Sima o el oficial austriaco de las Waffen SS Otto Skorzeny) y que no dudará en publicar material antisemita y neonazi en la década de los sesenta ${ }^{8}$. Pero otra parte de la publiciística y de la memorialística divisionaria vio la luz en editoriales modestas, de ámbito local o regional, muchas veces gracias a contactos personales. Con todo, las complicidades con los veteranos de la DA de la oficialidad del Ejército que había pasado por la campaña rusa, y el hecho de que muchos ex-combatientes de la DA obtuvieron puestos políticos de influencia en el nivel local y provincial-delegados provinciales de Ministerios, de Sindicatos, gobernadores civiles o cargos en la estructura del partido único, concejales, etcétera-, hizo posible su publicación.

Del mismo modo, Madrid, Barcelona, Valencia o Sevilla no contaron con ningún gran monumento dedicado a la DA durante el franquismo, y tampoco erigieron gran memorial alguno dedicado a los que en Rusia están. Sí fue cierto que calles dedicadas a la División Azul -y, asimismo, a los caídos de la División Azul- proliferaron en capitales de provincia y varias pequeñas ciudades, así como pequeños monumentos conmemorativos en algunas de ellas, como en Oviedo. Eso sin contar los varios monolitos y placas existentes en el interior de diversos acuartelamientos del Ejército español hasta el día de hoy. Con todo, la presencia en el callejero de la memoria de la DA fue muy inferior a la de la victoria del bando vencedor en la Guerra Civil: las calles dedicadas al 18 de Julio, al Alcázar de Toledo, a Franco, a José Antonio Primo de Rivera, a José Calvo Sotelo, e incluso las que llevaron nombres de generales del Ejército franquista (Mola, Yagüe, Sanjurjo o Moscardó), superaban en mucho al recuerdo urbano de la DA. Todavía en el año 2003, el número de municipios españoles con calles dedicadas a la División Azul era de 27 , un 0,32\% del total, incluyendo eso sí diez ciudades mayores de 60.000 habitantes (Alicante, Cáceres, Jerez de la Frontera, A Coruña, Jaén, León, Oviedo, Pontevedra, Santander y Toledo). Aún inferior es el número de municipios (17) con calles dedicadas al general Agustín Muñoz Grandes, primer comandante en jefe de la División hasta diciembre de 1942 , si bien todavía existe algún colegio público, como el de Mandayona (Guadalajara) que llevan su nombre. Héroes más locales, como el capitán cántabro

7. Vid. el recuento aproximado de publicaciones locales y regionales de las Hermandades de la DA desde su fundación en Blau División, n. ${ }^{\circ} 534$ (enero 2004), pp. 3-7.

8. Rooríguez Jiménez, José Luis, op. cit., p. 402. 
que fue prisionero en la URSS, Teodoro Palacios, cuentan con tres calles, dos de ellas en su región natal. Madrid, curiosamente, sólo conserva una calle dedicada a Muñoz Grandes y otra a los «caídos de la División Azul». En provincias con alta densidad de reminiscencias del bando vencedor en la Guerra Civil en su nomenclátor de calles, plazas, nombres de colegios, etcétera, como Ávila, no figura una sola referencia a la División Azul. En la provincia de Murcia, de 122 calles y plazas de reminiscencias franquistas, sólo cinco están dedicadas a la División Azul o a Muñoz Grandes, o sea el 4,09\%. Por su parte, en Mallorca hubo tres calles (de las que subsiste una) dedicadas a caídos o héroes locales de la División Azul, frente a 56 dedicadas a diversos mártires provinciales del bando franquista en la Guerra Civil, y una calle dedicada a esta última hasta $1979^{9}$. Numerosas localidades poseen, sin embargo, calles dedicadas a caídos o héroes locales de la DA en Rusia, si bien sus nombres ya poco evocan sesenta años después. Aunque la persistencia en el callejero urbano de la memoria de una unidad de voluntarios extranjeros encuadrada en la Wehrmacht constituye algo inédito en Europa occidental, se trata de un porcentaje prácticamente insignificante dentro de la propia pervivencia de los símbolos y lugares de memoria franquistas en la España democrática. Especialmente, si se le compara con los 828 municipios $(10,2 \%)$ que todavía poseen calles dedicadas a José Antonio Primo de Rivera, los $596(7,4 \%)$ donde aún existe una calle Calvo Sotelo, o los $522(6,4 \%)$ donde aún está presente de un modo u otro el nombre del Generalísimo Franco ${ }^{10}$.

Los caídos de la DA tendrán un reconocimiento simbólico durante el franquismo genéricamente semejante al de los "Mártires de la Cruzada", con el añadido de su paradero desconocido en tierra enemiga. Muchos de ellos, como ya mencionamos, dieron nombre a calles en sus localidades de origen. Pero sus hijos serían los falangistas modélicos, epígonos de los huérfanos de la Guerra Civil y ejemplos a seguir para sus jóvenes camaradas. Es el caso, por ejemplo, del leal jefe de escuadra de los flechas falangistas retratado en la historia «Cubre tu pecho de azul», de Julio Montañés, reproducido varias veces en el Manual del Acampado del Frente de Juventudes hasta los años 50, quien el domingo no recibía visitas de su familia por ser hijo de un caído de la DA y de una madre con muchos hijos... ${ }^{11}$. Sin embargo, los veteranos de la DA, pese a estar bien organizados, rara vez protagonizaron actividades de relieve público en «sus» fechas señaladas, que siguieron celebrando hasta el día de hoy en reuniones privadas, generalmente consistentes en misas por los caídos, actos en cementerios (ante el panteón de la Hermandad de la División Azul en el cementerio de la Almudena, por ejemplo) y comidas cada 10 de febrero en conmemoración de la batalla de

9. Instituto Nacional de Estadística, consulta DM 437/2003. Para los datos sobre Ávila y Murcia, vid. http://www.pce.es/foroporlamemoria/simbolos_franquistas.htm. Para Mallorca, vid. MAS QueTGlas, Joan, Els mallorquins de Franco. La Falange i el Moviment Nacional, Palma de Mallorca, 2003, pp. 332-346.

10. Datos elaborados por DUCH I Planas, Montserrat, "Toponimia franquista en democracia», en FORCADELL, Carlos, et al. (eds.), Usos públicos de la historia, Zaragoza, 2002, vol. I, pp. 377-390.

11. Reproducido en Otero, Luis, Flechas y Pelayos, Madrid, México y Buenos Aires, 2000, p. 166. 
Krasnij Bor (10 de febrero de 1943), así como eventualmente cada mes de julio (conmemoración de la partida de España en julio de 1941) o cada 12 de octubre (llegada al frente del Wolchow en 1941). Ni siquiera se registraron desfiles específicos de veteranos de la DA durante el franquismo. Lo más usual fue que se adhiriesen separadamente en cada capital de provincia al anual "Desfile de la Victoria” de cada primero de abril, marchando juntos en pequeños grupos, en algunas ocasiones, al final de la parada militar.

\section{UNA MEMORIA PECULIAR}

Aunque se airease lo menos posible su memoria pública, y en un primer momento se ocultase cuidadosamente la misma existencia de la DA al evocar la trayectoria de España durante la II Guerra Mundial, el régimen franquista tendió progresivamente a presentar a la DA como una empresa eminentemente anticomunista y precursora del enfrentamiento Este-Oeste, catolicismo frente a comunismo, oscureciendo la germanofilia de sus promotores y de muchos de los voluntarios en 1941. Aquí también podemos hablar de una paradoja: la memoria de la DA es la memoria amarga de los "perdedores» dentro del bando de los «vencedores». Es decir, la de aquellos sectores del régimen franquista que fracasaron en su intento por edificar una España auténticamente fascista, y que compartieron con sus aliados fascistas europeos la frustración del fracaso ante el poderoso enemigo soviético. Los divisionarios vivieron de algún modo el fracaso mundial del fascismo en la II Guerra Mundial, particularmente ante el Ejército soviético. Y muchos de ellos, particularmente los falangistas, no dejaron de sentirlo como propio: un lamento, como recogía Tomás Salvador en 1954, por «Europa. Europa amada, Europa indefensa, Europa violada y entregada»12.

Pero la DA fue también importante para la propia memoria profesional del Ejército español. Como tal. fue presentada como una más de las diversas y pintorescas expediciones militares en tierras exóticas que protagonizó aquél desde la campaña de Indochina en $1860^{13}$. Pues en la DA participaron oficiales y suboficiales reclutados exclusivamente en las filas del Ejército profesional, con lo que la unidad siempre se mantuvo bajo control de las jerarquías militares, sin que FET de las JONS pudiese ir más allá del patronazgo indirecto y de su influencia política sobre los voluntarios. Por la División Azul pasaron unos 166 jefes ( 2 generales, 16 coroneles, 42 tenientes coroneles y 128 comandantes), unos 2.030 oficiales y unos 4.083 suboficiales. Al decir de un miembro de la plana de enlace alemana de la DA en 1943, buena parte de las promociones salientes de la Academia de Oficiales habían pasado por la campaña de Rusia, lo que equivalía casi a un $30 \%$ de la oficialidad joven del Ejército español en

12. Salvador, Tomás, División 250, Barcelona, 1962 [1954], p. 365.

13. Así se aprecia, por ejemplo, en la obra escrita del general Emilio Esteban-Infantes, comandante en jefe de la DA desde diciembre de 1942. Vid. su libro Expediciones españolas del siglo XIX (Madrid 1949), que precede a su rememoración de la DA, La División Azul (Donde Asia empieza), Barcelona, 1956. 
aquel momento ${ }^{14}$. Muchos de esos oficiales, como los africanistas de veinte años atrás, ganaron experiencia de combate real y cierto prestigio ante sus colegas en un ejército que admiraban (la Wehrmacht) ${ }^{15}$, obtuvieron condecoraciones y ascensos en la campaña rusa, lo que les permitió adelantar puestos en el escalafón militar, al menos en comparación con sus pares que se habían quedado en España, y por lo tanto acceder de manera comparativamente rápida al generalato en las décadas siguientes. De hecho, un porcentaje más que apreciable de los mandos dirigentes del Ejército español durante el tardofranquismo y la Transición democrática sirvieron en la DA. Siete directores generales de la Guardia Civil entre diciembre de 1962 y octubre de 1983 habían sido oficiales en la DA entre 1941 y 1944, en rangos que oscilaban desde capitán a coronel. Además de ellos, un total de seis generales y ocho coroneles de la Guardia Civil sirvieron igualmente en el frente ruso como oficiales o suboficiales ${ }^{16}$. Y no menos de 300 oficiales que alcanzaron el rango de general en diversas armas ( 2 capitanes generales, 66 tenientes generales, 62 generales de División y 170 generales de brigada) pasaron por la División Azul ${ }^{17}$.

Ello explica también que en el seno del Ejército haya persistido una interpretación de la experiencia rusa no siempre coincidente con la cultivada por los círculos falangistas, pero igualmente benigna e idealizadora. Interpretación que sí fue bien tolerada por el régimen franquista, y tuvo continuidad en las Academias y cuarteles militares hasta el día de hoy. La socialización en la DA fue crucial para la generación militar que ocupaba los principales puestos en el generalato durante la Transición española. Pero esa experiencia, con ser significativa, no fue necesariamente determinante en sus alineamientos políticos a partir de $1975^{18}$. Para muestra un botón, si algo tenían en común varios de los altos mandos militares que fueron protagonistas la noche del 23 de febrero de 1981, tanto en el bando de los golpistas (el capitán general Jaime Miláns del Bosch, capitán condecorado en 1941-42, y el general Alfonso Armada y Comín, teniente en el cerco de Leningrado) como en el de los que permanecieron fieles a la Constitución (el general José Luis Aramburu Topete, director general de la Benemérita, capitán de zapadores distinguido en la batalla de Krasnij Bor en febrero de 1943, y el jefe del Estado Mayor del Ejército José Gabeiras Montero, también capitán en la campaña de Rusia) era el poseer la Cruz de Hierro de la Wehrmacht por su actuación en Rusia. También era ex-divisionario el general Alfonso Armada.

14. Informe del Dr. Haxel, Zustandbericht über die span. Freiw. Div, 11.8.1943, en Bundesarchiv-Militärarchiv (Freiburg), RH 24-50/59.

15. Vid. Cardona, Gabriel, El gigante descalzo. El ejército de Franco, Madrid, 2003, pp. 59-64.

16. Vid. García Hispán, José, La Guardia Civil en la División Azul, Alicante, 1991, pp. 77-80.

17. Datos extraídos de «Los generales de la División Azul. Investigación a cargo de Paco Grau», Blau Division, 539 (junio 2004), p. 6.

18. Es cierto, con todo, que entre los más conspicuos representantes del búnker integrista que en los años sesenta se organiza como grupo de presión dentro del régimen figuraban numerosos veteranos de la DA: varios de los fundadores de Fuerza Nueva Editorial en 1966 eran ex-combatientes, tanto civiles como militares en activo, de la DA, como Antonio Martínez Cattaneo. Vid. Rodríguez Jiménez, José Luis, op. cit, pp. 364-365. 
La DA ha generado en conjunto un número de libros de memorias, autobiográficos o biografías noveladas no inferior a ciento treinta y tres, entre 1942 y $2004^{19}$. A ellos se añaden varios cientos de relatos breves, tanto de carácter autobiográfico como de ficción más o menos novelada, publicados en tribunas diversas, particularmente en los diversos boletines que las asociaciones de veteranos de la DA siguen publicando con cierta regularidad hasta el día de hoy, convirtiéndose de esta manera en una de las asociaciones de veteranos de guerra españoles más activas en la actualidad. Prácticamente ninguna otra unidad participante en la II Guerra Mundial de dimensiones semejantes ha dado lugar a tanta literatura memorialística. Y mucho menos entre las "legiones extranjeras" del III Reich, cuyos veteranos publicaron en términos comparativos un número menor de testimonios y memorias ${ }^{20}$. Pero, igualmente, la que para algunos fue la "última gesta militar española del siglo XX" fue objeto de una atención literaria y publicística desproporcionadamente alta en comparación con otras guerras vividas por España o por soldados españoles. El número de autobiografías, por ejemplo, publicadas alrededor de la Guerra de África ha sido mucho menor, e incluso (en términos comparativos) las generadas por la Guerra Civil.

\section{Número de memorias publicadas de tema divisionario, 1942-2004}

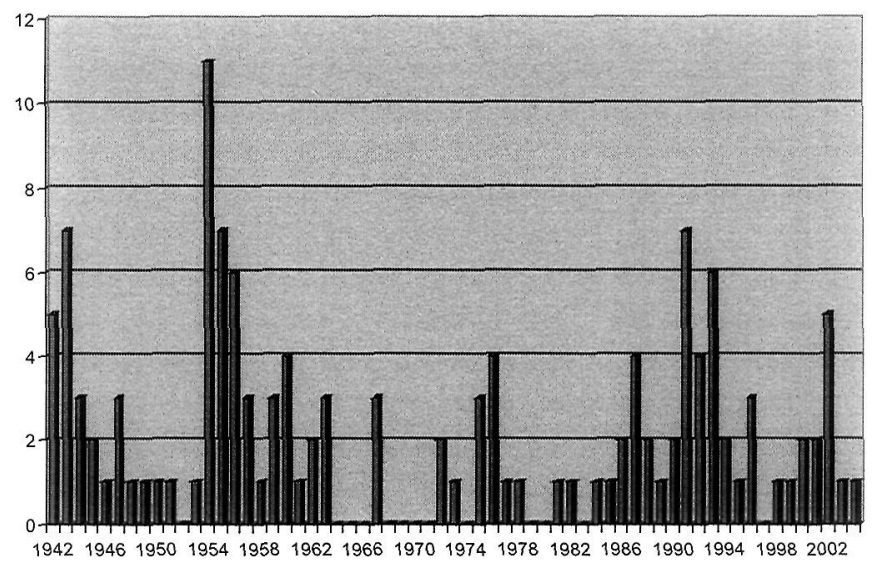

Fuente: elaboración propia. Sólo se incluyen autobiografías y memorias en formato de libro, sin añadir relatos aparecidos en publicaciones periódicas.

19. Hasta 1988, se contaban 136 títulos, entre libros, folletos, novelas y autobiografías: vid. CABALlero, Carlos e IBÁÑEz, Rafael, Escritores en las trincheras. La División Azul en sus libros, publicaciones periódicas y filmografía (1941-1988), Madrid, 1989. Sin embargo, el cómputo de estos autores incluye todo tipo de textos, incluyendo textos académicos o reflexiones sobre la DA sin ser autobiográficas.

20. Para un parangón con un caso concreto, la publicística generada por los antiguos voluntarios noruegos en las Waffen SS reclutados entre las filas del partido fascista y colaboracionista Nasjonal Sammling, vid. el artículo bibliográfico de DE FIGUEIREDO, Ivo, "De norske frontkjemperne-hva litteraturen sier og veien videre», Historisk Tidsskrift, n. ${ }^{\circ} 80$ (2001), pp. 531-551. 
¿Cuál es la razón de esa prolijidad? De entrada, un número de sobrevivientes muy alto en relación con el promedio usual en las unidades de la Wehrmacht que lucharon en el frente del Este: el $90 \%$ de los combatientes de la DA vivió para contarlo. Pues los sectores en que la División española estuvo destinada (el Wolchow, entre octubre de 1941 y agosto de 1942, y el sector sur del cerco de Leningrado, entre agosto de 1942 y octubre de 1943) fueron relativamente tranquilos, y particularmente a partir de diciembre de 1941 su función se limitó en la práctica a guarecer posiciones estáticas. Sólo en momentos puntuales las unidades de la DA que entraron en combate sufrieron un altísimo número de bajas. Los relevos comenzaron a llegar en marzo de 1942, y en general se puede estimar que el tiempo medio de permanencia en el frente de un voluntario de la DA fue relativamente breve en relación con el de un soldado alemán.

Pero, además de esa alta tasa de supervivencia, también influyó sobremanera a la hora de explicar la abundancia de testimonios el hecho de que buena parte de los combatientes voluntarios de la DA, particularmente los expedicionarios de la primera División de 1941 y de los primeros reemplazos del año 1942, fuesen estudiantes universitarios o militantes falangistas de cierta formación escolar e intelectual. Además de que varios escritores falangistas de cierto prestigio, como el poeta Dionisio Ridruejo o el novelista Tomás Salvador, se contaron entre quienes participaron en la aventura rusa, no hay que olvidar que un porcentaje más que apreciable de los voluntarios falangistas de la DA pertenecían a las secciones universitarias, estudiantiles y juveniles de FET, sobre todo al Sindicato Español Universitario $(S E U)^{21}$, y el recién nacido Frente de Juventudes. La combinación de entusiasmo juvenil, formación universitaria o al menos hasta el grado de bachiller, e idealismo fascista produjo un caldo de cultivo favorable para la aparición posterior de biografías y memorias, basadas a menudo en diarios personales de guerra. Muchos de los voluntarios alcanzaron tras 1944 puestos de cierto renombre en las letras, las artes o las ciencias - desde los cineastas Pedro Lazaga o Luis García Berlanga hasta el psicólogo José Luis Pinillos, pasando por el escritor satírico Álvaro de Laiglesia-, además de ocupar cargos en las jerarquías políticas de FET en el escalón provincial o regional, así como en las jerarquías castrenses. Sin embargo, pese a las tempranas previsiones de la prensa falangista ${ }^{22}$, los veteranos de Rusia no llegaron nunca a constituir una generación articulada capaz de dejar una impronta uniforme en el franquismo. Por el contrario, entre ellos reinó la variedad, reflejo de la propia heterogeneidad de la composición de la DA. Pero también gozaron, por su número, el prestigio y la cierta altura intelectual de bastantes de ellos, de una cierta auctoritas adicional a la hora de transmitir sus recuerdos. Ello hacía posible igualmente que sus escritos gozasen de una libertad relativa a la hora de ejercer

21. RuIz CARNICER, Miguel Ángel, El Sindicato Español Universitario (SEU), 1939-1965. La socialización política de la juventud universitaria en el franquismo, Madrid, 1996, pp. 143-147.

22. "La generación de los divisionarios", El Español, II:10, 2.1.1943, p. 2. 
la crítica velada al régimen franquista, particularmente a su deriva tecnocrática y católica que le alejaba de los iniciales postulados fascistas.

Naturalmente, esto también revestía otra consecuencia: la mayoría de las memorias corresponden a militares $y$, sobre todo, a voluntarios falangistas de primera hora con bagaje formativo. Ello condujo a una infrarrepresentación de autobiografías críticas con la DA, procedentes de aquellos combatientes que, particularmente a partir de mediados de 1942, no eran estrictamente voluntarios idealistas, sino que habían ido a Rusia más o menos forzados, obligados por la necesidad de procurar un sueldo adicional a su familia o, en algún caso, con ánimo de pasarse al Ejército Rojo. En términos generales, las biografías publicadas con anterioridad a 1975, y aún buena parte de las posteriores a esa fecha, transmiten una imagen altamente falangistizada de la DA, y por tanto tienden a homogeneizar y hasta a mitificar la pluralidad de motivaciones y situaciones que concurrían en los voluntarios. De este modo, la gesta divisionaria se reducirá casi exclusivamente a la llamada Primera División. Aquélla de los jóvenes idealistas del verano de 1941, que al decir de Dionisio Ridruejo atacarían a la bayoneta cantando canciones patrióticas y morirían en paz con Dios, con el Cara al Sol o un A Arriba España! en los labios, intentado dar al combate un aire épico de "emulación deportiva» que buscaba ante todo impresionar a sus camaradas alemanes ${ }^{23}$. Sólo excepcionalmente encontraremos con anterioridad a 1975 biografías y memorias en las que el autor no se confiesa falangista, sino simplemente «anticomunista» no simpatizante con el fascismo, aunque el énfasis siempre se situase tras 1945 en esta segunda etiqueta ${ }^{24}$.

Los veteranos de la DA volvieron a un país que no los trató como traidores o como asociales que se situaban al margen del nuevo consenso antifascista que legitimaba las democracias occidentales tras 1945. No sufrieron cárcel, exilio, privación de derechos civiles o depuración profesional. Por el contrario, al principio fueron recibidos como heroicos idealistas. Aunque el régimen franquista buscó por todos los medios una reconciliación con las potencias aliadas, y trató de borrar o diluir su pasado de colaboración estrecha con el III Reich, los veteranos de la DA siguieron gozando de la complacencia y hasta de la complicidad de buena parte de las jerarquías de FET-JONS y del Ejército, y por lo tanto de cierta capacidad de influencia. Además de ello, fue un hecho que una mayoría de los veteranos se benefició de las facilidades concedidas a los ex-combatientes a la hora de optar a puestos de la Administración pública de modo más o menos acorde a sus contactos previos y redes familiares, pero también a su formación. Los ex-divisionarios abundaron particularmente en servicios públicos como Correos y Telégrafos, en el escalafón medio y subalterno de diversos Ministerios, Ayuntamientos y Diputaciones, así como entre las filas de la Guardia Civil y la Policía. Igualmente, ya desde 1942 se registra la presencia de un buen número

23. Por ejemplo Hernández Navarro, Antonio José, Ida y vuelta, Madrid, 1971 [1946], pp. 110, 121 122 y 129; Ridruejo, Dionisio, Los cuadernos de Rusia, Barcelona, 1978, pp. 146-147, 158 y 166.

24. Por ejemplo, el conservador monárquico Ruddavets De Montes, Luis, Estampas de la Vieja Rusia (recuerdos de un voluntario de la División Azul), Madrid, 1960. 
de ex-combatientes de la División Azul, con o sin antecedentes falangistas, en las gestoras municipales de sus pueblos, como simples miembros o como alcaldes ${ }^{25}$. De este modo, aunque muchos de ellos eran partidarios de la profundización del contenido fascista del régimen, y contemplarán con desagrado su evolución hacia un catolicismo autoritario, no podían evitar ver sus perspectivas vitales y profesionales ligadas a la supervivencia del mismo régimen cuya claudicación lamentaban. Aunque la ostentación pública de simpatías por el III Reich era evitada en lo posible, en la práctica sólo los irreductibles, aquel medio millar que continuó combatiendo hasta abril de 1945 en las filas de la Wehrmacht o de las Waffen SS, tuvo dificultades reales para publicar sus memorias ${ }^{26}$.

Siguieron existiendo, con todos, espacios de tolerancia pública relativamente amplios para la reproducción de la memoria de la DA. Es más: en momentos señalados, particularmente al producirse la primera y masiva repatriación de prisioneros de guerra españoles de la URSS en 1954, se registró un importante repunte en la publicación de libros de memorias, que se ciñeron en buena parte a los oficiales y soldados que habían sido cautivos en la URSS ${ }^{27}$. Incluso, la gesta, ejemplificada en su resistencia en los diversos campos de concentración soviéticos durante más de una década, y el regreso de los prisioneros inspiraron varias novelas y piezas teatrales, que tenían como protagonistas a las mujeres y familias de los divisionarios presos y retrataban sus angustias durante su larga espera $^{28}$. Los cautivos, y particularmente los capitanes Teodoro Palacios Cueto y, en menor medida, Gerardo Oroquieta Arbiol, fueron convertidos por la propaganda oficial del régimen franquista en una suerte de heroicos defensores de la cristiandad y de la civilización occidental frente a la barbarie comunista, lo que

25. Para el caso de la provincia de Ciudad Real, vid. los datos aportados por González Madrid, Damián-Alberto, La Falange manchega (1939-1945). Política y sociedad en Ciudad Real durante la etapa "azul" del primer franquismo, Ciudad Real, 2004, pp. 324-355.

26. Fue el caso de uno de los pocos oficiales españoles que combatió tras 1944 en las Waffen SS, el capitán conquense Miguel Ezquerra, que hubo de publicar sus fantasiosas memorias en Portugal: vid. Ezouerra, Miguel, Lutei até ao fim: memórias dum voluntário espanhol na Guerra 1939-1945, Lisboa, 1947. Una versión más amplia del libro sólo fue publicada en castellano en 1975: Berlín a vida o muerte, Barcelona, 1975.

27. Vid. LuCA DE TENA, Torcuato y PAlAcios CueTo, Teodoro, Embajador en el infiemo: memorias del Capitán Palacios: once años de cautiverio en Rusia, Madrid, 1955; Oroouieta ArbIol, Gerardo y GARCía SÁnchez, César, De Leningrado a Odesa, Barcelona, 1958; Pérez Eizaguirre, Ramón, En el abismo rojo: memorias de un español, once años prisionero en la U.R.S.S., Madrid, 1955; NEGRO CASTRO, Juan, Españoles en la U.R.S.S., Madrid, 1959; Caidvia Bellosilio, Eusebio y Álvarez, Francisco, Enterrados en Rusia, Madrid, 1956; PoOuet Guardrola, Joaquín, 4045 dias cautivo en Rusia 1943-1954: memorias, Valencia, 1954. Todavía en la actualidad siguen apareciendo memorias de ex-cautivos: vid. Salamanca Salamanca, Ángel y Torres Garcia, Francisco, Esclavos de Stalin. El combate final de la División Azul (memoria histórica de un prisionero en la URSS), Madrid, 2002.

28. Por ejemplo Salom, Jaime, El mensaje, Madrid, 1963 (estrenada en 1955); MarTín Vicil, José Luis, La muerte está en el camino, Barcelona, s. E. [1956], o KuRTz, Carmen, El desconocido, Barcelona, 1972 [1956]. En cierto sentido, también Vascano, J. L., Infierno en la estepa, Valencia, s. f. [1960?]. 
concordaba con los nuevos tiempos de amistad con los Estados Unidos ${ }^{29}$. Ello incluyó el estreno de algunas películas que recreaban la odisea de los prisioneros españoles en el infierno comunista, entre ellas Embajadores en el infierno (1956) de José $M .{ }^{a}$ Forqué, basada en las memorias del capitán Palacios. Películas que no estuvieron exentas de polémica entre los medios falangistas, pues estos últimos consideraron que la identidad fascista de los voluntarios de la DA se diluía en un mensaje global de cariz anticomunista y católico, acorde con los tiempos, y confería protagonismo a los oficiales del Ejército profesional ${ }^{30}$.

Ello también nos da una muestra de por qué la literatura sobre la DA siguió siendo objeto de cultivo, hasta el punto de constituir por sí sola una suerte de subgénero dentro de la literatura fascista española ${ }^{31}$. El recuerdo de la DA no se presta a una interpretación unívoca. $Y$ aunque ese recuerdo fuese molesto para el régimen de Franco tras 1945, también fue susceptible de una reutilización propagandística adaptada a las nuevas circunstancias de la Guerra Fría, particularmente a partir de comienzos de la década de 1950. Al mismo tiempo, mediante una serie de recursos paratextuales y estrategias discursivas que expondremos a continuación, la publicística divisionaria pasó a desempeñar un papel no menospreciable en la justificación de la postura española en la II Guerra Mundial y en la fundamentación del papel de España como país católico que ya se había adelantado a las potencias occidentales en la lucha contra el comunismo. Ejemplar en este aspecto, por citar un caso, es la autobiografía de un ex-combatiente de la DA y después trabajador español en Alemania, Alberto de Lavedán, publicada a fines de los años cincuenta. En abril de 1945, Lavedán huyó a pie desde Berlín a Praga, donde pudo presenciar el levantamiento checo contra los alemanes y, a continuación, la entrada del Ejército Rojo. Su perspectiva, sin embargo, tendía a identificarse ahora con el mártir y patriota pueblo checo, además de resaltar que la DA había dado

...vigorosas lecciones de militante heroísmo anticomunista, con las armas en la mano, frente a las hordas soviéticas, que -joh, tragedia para Europa!- habrían de llegar, derrotada Alemania, con sus banderas rojas, sus violaciones, depredaciones, asesinatos colectivos y nefasta política de aherrojamiento de pueblos, hasta el mismo corazón sangrante de la Europa ecuménica, antigua y libre.

29. Vid. la tesis de licenciatura inédita de Morel, Sandra, "Le capitaine Palacios: construction d'un héro dans la période franquiste», Université de Marne-La Vallée, 1998.

30. Además de Embajadores en el infierno (1956), se estrenaron Las películas Carta a una mujer (Manuel Iglesias, 1961), La Espera (Vicente Lluch, 1956) y La Patrulla (Pedro Lazaga, 1954). Vid. Alegre, Sergio, El cine cambia la historia. Las imágenes de la División Azul, Barcelona, 1994; Bosoue ComA, Alfred, "La División Azul en la pantalla. Embajadores en el infierno", Historia y Vida, n. 299 (febrero 1993), pp. 66-73, así como la completa descripción de IBÁÑ̃ZZ HernÁNDEz, Rafael, "La cruzada antibolchevique en las pantallas. La División Azul en el cine y la televisión», Aportes, XVI: 2 (2001), pp. 36-53.

31. Vid. Rodríguez PuérTolas, Julio, Literatura fascista española, Madrid, 1986, vol. I, pp. 556-565. 
Pues miles de españoles habrían presentido ya en 1936 «la inquietud trágica de la actual GUERRA FRÍA dinámicamente agresiva de la Unión Soviética contra el mundo cristiano" ${ }^{32}$.

El leit-motiv de la publicística divisionaria tendrá ahora un claro norte. Se insiste en que los españoles lucharon junto a la Alemania nazi, pero no con o por el III Reich, sino contra un enemigo común, la URSS, en nombre de la defensa de la civilización occidental y europea, de la revancha de la Guerra Civil frente al comunismo soviético, y de los eternos valores católicos. Algunos de los testimonios publicados entre la década de 1950 y 1960 , como el del antiguo capellán castrense de la DA Ildefonso Jiménez Andrades, se centran claramente en vindicar el carácter exclusivamente anticomunista y hondamente católico de los voluntarios españoles, presentándolos como una suerte de nuevos cruzados henchidos de fervor cuasi-místico ${ }^{33}$. Y varios testimonios posteriores señalarán que ya en el momento de la jura de bandera en Alemania, muchos voluntarios abrigarían dudas en su fuero interno ante «unos principios que comenzaban a vislumbrar no eran del todo acorde con los suyos... y menos con la moral cristiana a la que estaban acostumbrados $»^{34}$. Por otro lado, el conjunto de experiencias vividas en Rusia, y transmitidas por los excombatientes, abonaría que la campaña en el frente del Este había sido, ni más ni menos, una continuación de la Guerra Civil, y una constatación en Rusia de los males que acarrearía el comunismo para los países que lo sufrían o habían sufrido. El trato dispensado a los cerca de 500 prisioneros españoles de la DA, sus penalidades en los gulags y campos de trabajo, así como su largamente demorada repatriación serían una demostración más del hecho de que España seguía siendo el país que más méritos había hecho, y más había sacrificado, en la lucha común de la civilización occidental contra el comunismo desde $1936^{35}$.

Tras la muerte del general Franco, en 1975, se añadió una nueva y paradójica motivación para alentar la continuidad de la publicística divisionaria: el reivindicar el ejemplo de la DA para el falangismo más o menos revolucionario e inconformista, pero asimismo como un ejemplo a seguir para las nuevas generaciones de la extrema derecha española, desorientada ante el éxito de la Transición y consolidación democrática en España y ante su propia debilidad electoral. Las publicaciones de memorias de antiguos combatientes serán alentadas, sobre todo, por algunas editoriales marginales -como las ediciones García Hispán, propiedad de un ex-militante de la organización neonazi CEDADE- y algunos jóvenes historiadores adictos al revisionismo historiográfico del Holocausto nazi, que igualmente estaban vinculados con las diversas tentativas de construir alternativas políticas de extrema derecha que superasen los esquemas ideológicos tardofranquistas, intentando una "vuelta a los orígenes»

32. DE LAVEDÁN, Alberto, Un español tras el telón de acero, Barcelona, s. E. [1959], p. 12.

33. Jimenez Andrades, Ildefonso, Recuerdos de mi campaña en Rusia, Badajoz, 1957; Vascano, J. L., op. cit., pp. 33-34.

34. Cogollos Vicens, José, ¿Por qué? Y ¿Para qué?, Valencia, 1985, p. 110.

35. Puente, Moisés, Yo, muerto en Rusia (Memorias del alférez Ocañas), Madrid, 1954, p. 39. 
del fascismo español. Esa búsqueda de un futuro en el pasado tendría su reflejo épico en el recuerdo de la DA. Recuerdo que constituía asimismo un motivo predilecto del minoritario neonazismo español, por causas obvias ${ }^{36}$. Con todo, ese revisionismo historiográfico, y hasta el filonazismo de algunos de sus promotores, convivía en difícil armonía con la cuasi-esquizofrénica necesidad de seguir insistiendo en el carácter diferencial de los voluntarios españoles de la DA y los posteriores de la Legión Azul y la Wehrmacht o en las Waffen SS. De este modo, el énfasis en la ausencia de antisemitismo entre los divisionarios, así como en su ejemplar comportamiento con la población civil rusa y polaca y el resaltar el claro contraste entre esa conducta y la del Ejército alemán da lugar a más de una paradoja en la publicística divisionaria posterior a la Transición.

Ciertamente, a partir de 1975 también se registró un interés memorialístico por resaltar la pluralidad de motivaciones que habían llevado a muchos españoles a alistarse en la DA. Aparecen así de modo más frecuente y con papel destacado en relatos y autobiografías nuevos personajes: opositores al régimen franquista que querían "hacer méritos» para redimir procesos judiciales pendientes contra ellos o sus familiares; soldados de leva conminados por sus superiores a apuntarse a las expediciones de relevo tras 1942; comunistas españoles que querían pasarse al Ejército Rojo en cuanto tuviesen la oportunidad; legionarios alistados en los reemplazos por aventurerismo, deseo de pasarse al enemigo o simple coacción... ${ }^{37}$. Incluso, una autobiografía novelada sobre tema divisionario, publicada en 2001, pretendía trazar una suerte de simbólica reconciliación final entre las Españas enfrentadas en 1936-45: el encuentro entre un antiguo oficial de la DA fiel a los postulados falangistas y anticomunistas, y un «niño de la guerra» enrolado como partisano en el Ejército Rojo que se pasó a la DA en 1943 para poder retornar a España, y que guardaba un buen recuerdo de ambos ejércitos ${ }^{38}$. Este tipo de biografías, sin embargo, será mucho menos abundante dentro del total.

La descomposición de la URSS en 1991 y el fin del "socialismo real» contribuyeron, finalmente, a avivar el interés de muchos ex-divisionarios avanzados en edad por publicar sus memorias, en parte acompañadas de un viaje sentimental al lugar de sus aventuras. Su lucha contra el comunismo y sus sufrimientos se verían así simbólicamente compensados con la visita a una Rusia liberada.

36. Vid. Casals, Xavier, Neonazis en España. De las audiciones wagnerianas a los skinheads (1966-1995), Barcelona, 1995, pp. 177 y 315-316.

37. Vid. por ejemplo GARCíA DE LEDESMA, Ramiro, Encrucijada en la nieve. Un Servicio de Inteligencia desde la División Azul, Granada, 1996; González, Fernando, Memorias de un fascista español, Madrid, 1976, pp. 95-162; Cogolios Vicens, José, op. cit.; Linares, Vicente, Más que unas memorias. Hasta Leningrado con la División Azul, Madrid, 2000; el dudoso testimonio de MESAdo i Mañé, Manel, Memòries d'un temps gris. Un borrianenc en la División Azul, Borriana, 2002; SÁnCHEz SalCEDo, Eduardo, Framan (de Serrablo a Leningrado), Sabiñánigo, 2002. Vid. también los testimonios recogidos en Acustí Roca, Carme, Rússia es culpable! Memòria i record de la División Azul, Lleida, 2003 .

38. FeRnández BlanCo, Laurentino, Recuerdos de la División Azul. Fui guerrillero (1941-1943), Madrid, 2001. 
Lo que podemos denominar el relato divisionario elaboró, además, una suerte de ciclo mítico que se autorreproduce de modo constante. En ese relato, existen una serie de hitos omnipresentes, de etapas que, en cierto modo, se presentan como una suerte de viaje iniciático desde la inocente e idealista juventud hasta la madurez $y$, a menudo, el desencanto, representado por el encuentro con la guerra y las duras condiciones de la retaguardia. Tenemos así varias estaciones definidas en ese viaje. Primera, el alistamiento y el viaje a Alemania en tren. Segunda, la instrucción en los campos militares de Grafenwöhr o Hof y el encuentro con el Ejército alemán. Tercera, la marcha hacia el frente, parcialmente a pie en el caso de la "primera División» del verano de 1941. Cuarta, la estancia en el frente y la participación en diversas acciones militares de mediana envergadura. Quinta, las realidades de la vida cotidiana en el frente ruso: el contacto con la población civil de las aldeas ocupadas, pero también las penalidades del medio (la nieve, el frío, el barro de la estación del deshielo, los mosquitos del verano, el hambre...). Sexta, el regreso a España, previo paso por uno o varios hospitales de campaña y el encuentro en "escapadas» con población civil letona o alemana en la retaguardia, elemento casi omnipresente en las autobiografías. Pero aún se añadían nuevas estaciones a esa suerte de via crucis. La séptima estación sería el episodio efímero de la llamada Legión Azul, es decir, el cuerpo remanente de combatientes que teóricamente debería haber permanecido en el frente del Este hasta el final, entre octubre de 1943 y marzo de 1944 con una ejecutoria irrelevante en términos militares. La octava, envuelta en un halo de misterio legendario, los llamados «irreductibles», aquellos que desafiaron las órdenes del régimen franquista y se enrolaron directamente en la Wehrmacht y las Waffen SS, hasta combatir en las ruinas de Berlín, y su azaroso regreso. La novena, las vicisitudes de los prisioneros de la DA que permanecieron en cautiverio en la URSS, hasta la repatriación y apoteósico regreso de la mayoría de ellos en abril de 1954.

El ciclo parecía cerrado a mediados de los años cincuenta. Sin embargo, distaba de estarlo, como mostrará el resurgir de la memorialística divisionaria en los años de la Transición y particularmente a partir de 1989-90. Pues aún quedaban pendientes dos estaciones más, consistentes en lo que podríamos denominar los dos retornos simbólicos, que se podrán verificar a partir de los años ochenta y, particularmente, desde la desaparición de la Unión Soviética en 1991. La décima estación serían los regresos de veteranos a los escenarios de los frentes de combate, particularmente frecuentes desde mediados de la década de los ochenta $y$, particularmente, a partir de 1989. Y la undécima estación, que pondría el punto final y que suponía un paso más allá del culto permanente a las imágenes fotográficas y pictóricas de los cementerios españoles de campaña, donde reposarían los héroes cuya sangre habría regado el territorio enemigo. Se trataba del retorno físico a España de los restos de los más de 4.000 divisionarios enterrados en Rusia, "gran obligación moral y material del pueblo español», que en la actualidad se mantiene como reivindicación por una parte importante 
de los veteranos; y que ha hallado un cierto eco en la opinión pública conservadora y entre los varios miles de parientes y descendientes de los $\operatorname{caidos}^{39}$.

\section{LOS TÓPICOS DEL RELATO DIVISIONARIO}

Las circunstancias antedichas han condicionado los marcos sociales de la memoria colectiva e individual de la División Azul ${ }^{10}$. Considerada como un tipo ideal, la narrativa divisionaria, basada en libros de memorias y novelas de inspiración autobiográfica, pero también ayudada por su reproducción en el cine y la prensa, ha elaborado una serie de estrategias y recursos textuales y paratextuales que articulan de modo conjunto un auténtico relato performativo acerca de la experiencia individual de los antiguos combatientes, pero también de la División Azul como un colectivo. Narrativa que ha conseguido, en cierto modo, imponerse como el auténtico relato sobre la DA que es hegemónico en la memoria del franquismo y del propio Ejército español, pero también en buena parte de la esfera pública española desde la Transición ${ }^{41}$. Se trata de un discurso que, como en la mayoría de las autobiografías de guerra, parte de reflexiones y reconstrucciones individuales del pasado, pero presenta a su vez una clara voluntad de vindicación e identificación colectiva de un grupo que, virtualmente, se traslada al presente desde la idealización de la camaradería de otrora, mediante una suerte de pacto semiconsciente entre individuo y colectivo, entre pasado rememorado y construido ${ }^{42}$. Estrategia que se extiende igualmente a las formas más o menos ficcionalizadas de reproducción de esa reconstrucción del pasado, que articulan a su vez una forma de expresión complementaria de la memoria colectiva de la $\mathrm{DA}^{43}$.

¿Cuáles son los elementos más característicos, y hasta cierto punto distintivos, de ese relato divisionario que también presenta rasgos peculiares en relación con la memoria alemana o italiana de la experiencia del Frente del Este? Podemos resumirlos, en nuestra opinión, en los siguientes apartados:

39. Vid. Garrido Polonio, Femando y Garrido Polonio, Miguel Ángel, Nieve Roja. Españoles desaparecidos en el frente ruso, Madrid, 2002. Las Hermandades de la División Azul ya en 1991 proclamaban su objetivo de devolver los restos de los caídos en Rusia a España: vid. VidAl y GADEA, José Antonio, Breves notas sobre la División Azul, Alicante, 1991, p. 62.

40. HalbWACHS, Maurice, La memoria colectiva, Zaragoza, 2004 [1925].

41. Para más detalles, vid. nuestro artículo ««ussland war nicht schuldig». Die Ostfronterfahrung der spanischen Blauen Division in Selbstzeugnissen und Autobiographien, 1943-2004", en HaGemann, Karen, EPKenhans, Michael, y Förster, Stig (eds.), Soldat und Gesellschaft. Biographien und Seltbstzeugnisse in der Militärgeschichte, Paderborn, 2005.

42. Rosenthas, Gabriele, "Narración y significado biográfico de las experiencias de guerra», Historia y Fuente Oral, n. 4 (1991), pp. 119-128; LejeUne, Philippe, El pacto autobiográfico y otros estudios, Madrid 1994, pp. 50-51; Rucoeur, Paul, La mémoire, /Tistoire, l'oubli, París, 2000.

43. FARruGia, Francis, "Síndrome narrativo y reconstrucción del pasado», Historia, Antropología y Fuentes Orales, n. ${ }^{\circ} 32$ (2004), pp. 133-150. 


\section{a) Yo tenía un camarada... desencantado}

En primer lugar, es de destacar el acusado idealismo, de impronta falangista en la gran mayoría de los casos, presente en casi todos los relatos. Idealismo que se combina, de modo más o menos variable, con un ácido desencanto, tanto más patente cuanto más lejana en el tiempo es la evocación ${ }^{44}$. El desencanto nace en buena parte, como en toda memoria de veteranos de guerra, de la idealización entre el mundo "auténtico", "viril», interclasista e idealista sin artificios retóricos de las trincheras; y que es evocado a posteriori, desde la madurez, como un duro contraste con el materialismo ruin e hipócrita imperante en la vida civil ${ }^{45}$. Esa camaradería, como en la mayoría de las biografías de guerra, se circunscribe al pelotón o al pequeño grupo combatiente, con el que se comparte trinchera y chabola, a los oficiales de rango inferior y como mucho al comandante del batallón. Pero, al mismo tiempo, el hecho de que en la DA se diesen cita voluntarios que provenían de grupos políticos y estudiantiles relativamente reducidos provocaba que la DA fuese un "pequeño mundo" donde, fuera de la propia compañía o sección, siempre era posible encontrar familiares próximos o lejanos, conocidos, antiguos camaradas de armas de la Guerra Civil o del falangismo «de combate» de los años treinta, tanto en otras unidades y compañías como en los hospitales de campaña españoles de Riga, Vilnius o Königsberg. La cohesión de la camaradería de la DA, sobre todo hasta mediados de 1942, se explica por esa fusión de "grupos primarios» de origen y nuevos grupos de lucha y camaradería sólidamente cimentados en la experiencia común del combate y la convivencia cotidiana con el peligro, el tedio de la trinchera, los piojos y la suciedad ${ }^{46}$. El carisma personal y la gran popularidad entre los divisionarios, sobre todo entre los voluntarios del verano de 1941, del general Agustín Muñoz Grandes, primer comandante en jefe de la DA hasta diciembre de 1942, también reforzaba esa cohesión. Muñoz Grandes, secretario general de FET de las JONS entre agosto de 1939 y abril de 1940, conseguía aunar en su figura el prestigio militar y el político, además de un cierto carácter populista ${ }^{47}$.

44. Ejemplar (e irónico) en este sentido es la ficcionalización de un encuentro entre varios ex-divisionarios barceloneses, que se reúnen en 1974 para asistir al entierro de un antiguo camarada, en SALVAdOR, Tomás, Camaradas 74, Barcelona, 1975.

45. Ejemplar en este sentido es el breve folleto de URGorm y BAS, Carlos, Prólogo al tema Amistad, Madrid, 1987, donde el autor evoca la camaradería entre los miembros de su pelotón en Rusia. Igualmente, vid. las reflexiones del protagonista de Hernández NAVARro, Antonio José, op. cit., pp. 245-46, acerca de la difícil reincorporación a la vida civil de los veteranos y su rebeldía frente a sus normas, falsedades y frivolidades: en el mismo sentido, vid. García LUNA, José, Las cartas del Sargento Basilio, Barcelona, 1959, pp. 80-81 y 251-257; o Royo MAsía, Rodrigo, , Guerra! Historia de la vida de Luis de Pablos, Madrid, 1944, pp. 157-59, acerca del carácter "auténticon y descarnado, pero sincero, de las relaciones entre los que compartían una misma posición.

46. Sobre el debate acerca de la fortaleza de los "grupos primarios" en la Wehrmacht como razón de la extraordinaria resistencia y fidelidad del Ejército alemán hasta la capitulación final, vid. BARTOV, Omer, Hitler's Ammy, Soldiers, Nazis, and War in the Third Reich, Nueva York / Oxford, 1991, pp. 29-58.

47. Sobre Muñoz Grandes falta un estudio basado en fuentes innovadoras. Buenos ejemplos del persistente culto divisionario a su personalidad en BERG, Helmuth, Generalleutnant Agustin Mi- 
Esta popularidad trascendió más allá de la publicística divisionaria. E incluso se proyectó a ámbitos literarios más amplios que no respondían para nada al relato divisionario: recordemos la admiración que profesaba a Muñoz Grandes el entrañable personaje Bromuro, limpiabotas ex-divisionario y confidente del detective de ficción Pepe Carvalho creado por el malogrado novelista Manuel Vázquez Montalbán.

La segunda fuente del desencanto, sin embargo, era meramente política. La camaradería de cariz fascista "revolucionario" de la DA no había encontrado un reflejo en las actitudes de las jerarquías del régimen franquista, acomodadas cuando no corruptas, desviadas de los objetivos "primigenios» y fundacionales del fascismo español. Pues los antiguos camaradas falangistas que no habían ido a Rusia habrían sucumbido al materialismo. Buena parte de los voluntarios de la DA se presentaron como los últimos y frustrados fascistas verdaderos de España. Por ello, también cultivaron una imagen de sí mismos como últimos románticos, elementos incómodos que permanecían fieles a los ideales revolucionarios de juventud y menospreciados por las jerarquías del partido único franquista, que ya habían ido a Rusia disconformes con el rumbo que tomaba la preterida revolución falangista soñada en 1936: "por no saber nada de las mezquindades y crímenes de la retaguardia", escribía José Manuel Castañón, "me he venido de nuevo al frente soñando en un futuro ordenamiento de Europa que ordene también a España», al igual que "muchos falangistas nobles [que] se han alistado en la aventura para no emponzoñarse en la paz» ${ }^{48}$. El malagueño Rafael Castaño escribirá en 1990 que hedillistas, ex-divisionarios y falangistas revolucionarios se convirtieron tras 1945 uen unos proscritos y marginados. Algunos marchamos desde entonces a la deriva" ${ }^{49}$. Por ello, en cierto sentido, los divisionarios se considerarán a sí mismos como los vencidos dentro de los vencedores. Naturalmente, otra cuestión es que esa imagen se corresponda con una discriminación laboral y social en el terreno de los hechos. Como ya vimos, la integración sociolaboral y hasta política de los antiguos divisionarios fue mucho más exitosa de lo que ellos mismos reconocieron en sus memorias.

\section{b) Luceros y sangre en la nieve}

En segundo lugar, las autobiografías y memorias que versan sobre la DA también se caracterizan por un acusado realismo, en ocasiones denominado "tremendismo realista». Aquél se manifiesta particularmente al describir minuciosamente las penalidades de la guerra, y en el gusto por la descripción fiel y casi meticulosa de la dura realidad del combate y la trinchera. Algo que ya había

noz-Grandes: Spaniens "Blaue Division» an der Ostfront, Rastan, 1963 y VADlLLO, Fernando, Muñoz Grandes, el general de la División Azul, Madrid, 1999.

48. Castañon, José Manuel, Diario de una aventura (con la División Azul 1941-1942), Gijón, 1991, pp. 81 y 100.

49. Castaño Doña, Rafael, Legionario en Rusia, Alicante, 1991, p. 104. 
aparecido en la literatura biográfica y novelística sobre la Guerra Civil, o la más reducida sobre la Guerra de Marruecos.

Sin embargo, ese cruel realismo, brutal en ocasiones, coexiste con el más acusado y retórico lirismo, algo típico del estilo literario falangista, que contribuye a su vez a engrandecer el aura romántica y aventurera de la experiencia transmitida. El resultado es una mezcla, a menudo muy inestable, de lirismo y tremendismo. La descripción acre de las condiciones de los hospitales de campaña, el gusto por reflejar la dureza del lenguaje cuartelero y la hosquedad de las relaciones humanas en el ejército, la narración de agonías y muertes violentas, dejan paso inmediatamente en la mayoría de los casos a bellas imágenes literarias. Por ejemplo, la evocación sentida pocas líneas más adelante del nevado paisaje ruso en términos grandilocuentes, buscando paralelismos con el misticismo del paisaje castellano; o bien la contemplación de las noches estrelladas por los centinelas solitarios como un recuerdo a los camaradas muertos, a los "luceros» de la noche que, como rezaba el Cara al Sol, hacían guardia y marcaban el camino a seguir a sus compatriotas vivos, de acuerdo con el clásico concepto falangista de la vigilia, la revolución pendiente que reclamarían los $\operatorname{caidos}^{50}$. O bien, en fin, la inmensidad del paisaje ruso, las estepas nevadas y los ríos helados, que provocan arrebatos de lirismo en la mayoría de las descripciones que inciden en la presentación del soldado español como un ser perdido en el infinito. Con ello, el voluntario adquiriría mayor conciencia de su misión trascendental en pos de sus ideales, de ser una avanzadilla de la nueva voluntad de imperio español que pregonaba el falangismo, y que persistiría en una tierra fecundada por los muertos españoles de cuyas tumbas florecerían "margaritas silvestres y flores amarillas» ${ }^{51}$.

\section{c) Una guerra limpia: los silencios de una guerra de exterminio}

Aquel realismo, sin embargo, también presenta sus claros matices. Hay tabúes que rara vez se rompen, típicos también de los testimonios autobiográficos de combatientes alemanes y de otras nacionalidades en el frente del $E_{s t}{ }^{52}$. El llamado "mito de la Wehrmacht", generado en la opinión pública de la República Federal Alemana durante las décadas del 50 y 60 , y que se puede resumir en la presunción de que las tropas regulares integradas en el Ejército alemán habrían tenido una conducta noble e impoluta en su ejecutoria bélica,

50. Pérez Bowie, José Antonio, "En torno al lenguaje poético fascista. La metáfora de la guardia eterna", Letras de Deusto, vol. 31:15 (1985), pp. 73-96. Buenos ejemplos en Hernández NavarRo, Antonio José, op. cit., pp. 99-100, 121-122 y 129, así como en Farré Albinana, Jaime, 4 infantes 3 luceros, Tetuán, 1949.

51. Un buen ejemplo en Hernández Navarro, Antonio José, op. cit., pp. 99-100, 121-22 y 129. O bien el folleto de Fernández Velasco, Adolfo, El relevo del Alcázar, Benicarló, 1943. Vid. igualmente ANDÚyar, Antonio, "Cuando dejamos el Ilmen», Hoja de Campaña, n. 85, 19.9.1943, p. 2, y SÁnCHEz Carrilero, Javier, Crónicas de la División Azul, Albacete, 1992, pp. 53-65.

52. Vid. WETTE, Wolfram, Die Wehrmacht. Feindbilder, Vernichtungskrieg, Legenden, Frankfurt am Main, 2002, pp. 180-181 
mientras las atrocidades y crímenes contra partisanos y población civil serían responsabilidad exclusivamente de las Waffen $\mathrm{SS}^{53}$, tuvo un reflejo directo igualmente en la memorialística divisionaria. Con un matiz: la División Azul habría tenido un comportamiento aún más limpio y honorable que la limpia y honorable Wehrmacht.

Entre esos silencios se pueden señalar los siguientes:

1) Los maltratos físicos y psíquicos a civiles, particularmente a campesinos rusos, que, aunque de modo menos sistemático y brutal que los ocupantes alemanes, también tuvieron lugar, sobre todo en represalia por ataques partisanos a soldados españoles;

2) Las menciones a ejecuciones de prisioneros, que sólo aparecen en contadas ocasiones, y eso a partir de la década de 1990. Del mismo modo, tampoco se menciona en ninguna memoria o autobiografía la práctica corriente de fusilar inmediatamente a los comisarios políticos del Ejército soviético que eran capturados en combate, de acuerdo con las instrucciones para la conducta de las tropas alemanas en Rusia recibidas por todas las unidades participantes en la Operación Barbarroja en junio de 1941, dictadas por el Alto Mando de la Wehrmacht, y que estuvieron en vigor al menos hasta el verano de 1942.

3) Las deserciones en las propias filas (más frecuentes a partir de 1942), sólo aludidas de manera indirecta y pasajera, y particularmente en los retratos despectivos del comportamiento traidor de los desertores que compartieron el mismo cautiverio que los prisioneros de guerra españoles; igualmente, también se silencian cuidadosamente los fusilamientos de camaradas sorprendidos en intento de deserción, o cuyas prácticas de automutilación para evitar el combate fueron descubiertas por sus oficiales.

4) Además de ello, habría que añadir los tabúes sexuales, algo típico de toda la literatura militar, básicamente resumibles en dos temas: violaciones o abusos contra mujeres civiles rusas y relaciones homosexuales entre los propios soldados, muy raramente mencionadas ${ }^{54}$. La visita a los prostíbulos organizados por el Ejército alemán en la retaguardia para satisfacer los deseos sexuales de los soldados de la Wehrmacht sí puede hallar menciones esporádicas, particularmente a la hora de detallar -como rareza- las precauciones profilácticas dictadas por las autoridades militares alemanas. Para nada, sin embargo, aparecen en los testimonios de soldados españoles referencias a las mujeres eslavas, judías

53. Vid. Heer, Hannes, Tote Zonen. Die deutsche Wehrmacht an der Ostfront, Hamburgo, 1999, p. 180 y ss.; PätzoLD, Kurt, Ihr waret die besten Soldaten. Ursprung und Geschichte einer Legende, Leipzig, 2000, así como BALD, Detlef, KLoTz, Johannes y WeTtE, Wolfram, Mythos Wehrmacht. Nachkriegsdebatten und Traditionspflege, Berlín, 2001. Vid. igualmente We1TE, Wolfram, Die Wehrmacht..., pp. 195-244.

54. Excepciones en SÁnCHez SALCEDo, Eduardo, op. cit., pp. 64 y 66; ZulAiCA, Ramón, La última oportunidad, s. 1. [San Sebastián], 1963; Ydígoras, Carlos M. ${ }^{a}$, Algunos no hemos muerto, Madrid, 1984 [1957], pp. 139-40 y MELIÁ VILA, José, Bajo 6 banderas con la muerte en los talones. Año 1936 a Diciembre de 1943, s. 1. [Valencia], 2003, p. 76. 
o bálticas reclutadas por el Ejército ocupante a la fuerza para servir en esos burdeles ${ }^{55}$.

5) Igualmente, la descripción de acciones de represalia contra partisanos o población civil sospechosa de colaborar con ellos serán también casi inexistentes hasta la década de 1980, pese a que las fuerzas españolas y la Feldgendarmerie de retaguardia del frente, cuya labor desempeñaban en el sector español voluntarios de la Guardia Civil, tenía entre sus cometidos la lucha antipartisana. Las campañas contra los partisanos, como mucho, sólo aparecen en los relatos publicados durante el franquismo como escenas contempladas al paso de la DA por Polonia y Rusia camino del frente, obra por supuesto de tropas alemanas o de las omnipresentes Waffen SS, cuerpo aparte del que se abjura.

6) Del mismo modo, como veremos, el tratamiento de la cuestión judía, y particularmente del contacto entre soldados españoles y población judía en Polonia y Lituania a lo largo de la marcha a pie en septiembre de 1941, variará ostensiblemente entre las primeras descripciones (1943-46), y las publicadas a partir del conocimiento del Holocausto. Con anterioridad a 1946, los tonos despectivos hacia los hebreos no eran rareza, al igual que en varios diarios de campaña ${ }^{56}$. Lo que se correspondía con el antisemitismo cultural y religioso que también anidaba en el fascismo español desde los años treinta, y del que hacían gala, por ejemplo, los varios poemas escritos en honor de los voluntarios que marcharon a Rusia en el verano de $1941^{57}$. Tras el final de la II Guerra Mundial, muchos veteranos afirmarán no dar crédito a la propaganda aliada. Pero el peso de la evidencia también les forzó progresivamente a marcar las distancias con el III Reich y el Ejército alemán como autojustificación, mediante la reproducción de diversas anécdotas vividas por los divisionarios y que insistirían en su defensa ocasional y aislada de hombres y mujeres judíos frente a abusos alemanes ${ }^{58}$. Se elaboró así un discurso performativo que ha sido aceptado con cierta frecuencia y hasta ingenuidad como la recreación de la realidad en sí por algunos historiadores que reproducen su visión sin demasiados matices y pre-

55. El tema, de hecho, sólo recientemente ha sido abordado de forma concluyente por la historiografía alemana. Vid. Beck, Birgit, Wehrmacht und sexuelle Gewalt. Sexualverbrechen vor deutschen Militärgerichten 1939-1945, Paderborn, 2004.

56. Vid. por ejemplo Gomez Tello, José Luis, Canción de inviemo en el Este: crónicas de la División Azul, Barcelona, 1945; más reflexivo, reconociendo que los judíos le causaban "repulsión", pero rechazando la persecución fría y sistemática, era RIDRUejo, Dionisio, op. cit., pp. 40, 42-43, 53, $60-64$ y $80-81$.

57. Sobre la retórica y contenidos antisemitas del fascismo español, vid. Álvarez ChILLIDA, Gonzalo, El antisemitismo en España. La imagen del judio (1812-2002), Madrid, 2002, pp. 381-420 y BÖCKER, Manfred, Antisemitismus ohne Juden. Die Zweite Republik, die republikanische Rechte und die Juden. Spanien 1931-1936, Frankfurt a. M., 2000. Ejemplos de referencias antisemitas coetáneas a la partida de la DA en CuArtero, Arturo, Los que se marchan. La División Azul, Madrid, s. f. [1941], pp. 23-25, y Carkión, Desiderio, ;Voluntariado español!, Quintanar de la Orden, 1941.

58. VaDilio, Fernando, Orillas del Voljov, Barcelona, 1967, pp. 134-35, 156, 159-166, 180 y 186-94; paradigmático, sobre todo, el relato novelado de BARS CASAMmANA, Manuel, El pan en el fango, Olot, 1962. 
sentando a los divisionarios incluso como cándidos y generosos protectores de los judíos ${ }^{59}$.

Ello constituye cuando menos una generalización discutible. De entrada, los españoles nunca plantearon conflictos de entidad al mando alemán por su desacuerdo con la política racial del III Reich. Hubo, eso sí, pequeños incidentes esporádicos entre soldados españoles y alemanes por ese motivo, pero las autoridades militares alemanes nunca consideraron que esos incidentes fuesen más importantes, por ejemplo, que los provocados por los "asaltos de todo tipo contra la población, incendios, robos, saqueos, hurtos, delitos sexuales etcétera" que desde 1941 acompañaban la presencia de voluntarios españoles en la retaguardia ${ }^{60}$. Se pueden citar ejemplos más contundentes de protección de judíos por parte de las tropas italianas en el frente del Este, por ejemplo, por no hablar de los conflictos abiertos entre el Ejército alemán y el italiano en las zonas ocupadas de los Balcanes por ese motivo ${ }^{61}$. Es cierto que en los hospitales españoles de Riga y Königsberg se empleaba personal auxiliar judío en igualdad de condiciones con españoles, alemanes y bálticos, así como que algunos testimonios hablan de la propensión de los voluntarios españoles a tener contacto sin prejuicio alguno con la población hebrea, tanto a su paso a pie por las zonas orientales de Polonia y Lituania como en sus estancias en retaguardia en Vilnius - Riga ${ }^{52}$. Pero, al mismo tiempo, en varias autobiografías de divisionarios -sobre todo las de aquellos veteranos vinculados a las Hermandades de la División Azul- se insiste repetidamente en que el "problema judio", pese a existir, había sido exagerado por los medios de comunicación; aunque a continuación se describiesen anécdotas en las que el protagonista había sido testigo de malos tratos a la población hebrea, había confraternizado con judíos e, incluso, se había enfrentado a algún guardia alemán ${ }^{63}$.

59. En mi opinión, es el caso de Bowen, Wayne, «A Great Moral Victory»: Spanish Protection of Jews on the Eastern Front, 1941-1944", en RoHruch, Ruby (ed.), Resisting the Holocaust, Oxford / Nueva York, 1998, pp. 195-211.

60. Carta del Comandante General de las Tropas de Protección de Retaguardia [Sicherungstruppen] del Grupo de Ejércitos Norte al Comando Supremo del Grupo de Ejércitos Norte, 5.2.1944 (BA$\mathrm{MA}, \mathrm{RH}$ 19-III/774).

61. Vid. MichaelIS, Meir, Mussolini and the Jews: German-Italian Relations and the Jewish Question in Italy, 1922-1945, Oxford, 1978, p. 321 y WetTe, Wolfram, Die Wehrmacht..., pp.136-140.

62. Por ejemplo, if. el informe del capitán Collatz, Plana de Enlace Alemana en la DA, a Grupo de Ejércitos Norte, 23.10.1941 (BA-MA, RH 19-III/774). O las anotaciones del Diario de guerra de la Plana de Enlace alemana de la DA, entradas del 26.8, 1.9 y 6.9.1941 (BA-MA, RH 26-250/2). Testimonios polacos, aunque no suficientemente contrastados, en MuszYnsKi, Wojciech Jerzy, Blekitna dywizja. Ochotnicy Hiszpanscy na froncie wschodnim 1941-1945, Varsovia, 2002, pp. 19-20.

63. Por ejemplo, ChICharro Lamamí De Clatrac, Juan, Diario de un antitanquista en la División Azul, Madrid, 2001, pp. 19-22. 


\section{d) Un juego de espejos, o el indómito y anárquico español versus el rigido tudesco}

Tal vez el rasgo más sobresaliente de la memorialística divisionaria sea éste: un acusado tipismo, es decir, un particular gusto en describir de forma estereotípica las costumbres y reacciones del español popular y castizo, o típicamente hispánico. Ello se manifestaba, sobre todo, en el particular deleite en la exposición del contraste entre el estereotipado carácter español, meridional y alegre en una tierra esteparia y fría, y el carácter y psicología colectiva de las nacionalidades y pueblos con los que entró en contacto y relación a lo largo de la campaña rusa. Fundamental en este manejo del tipismo es el constante recurso a los estereotipos sobre el Otro, expresados en multitud de anécdotas, observaciones y detalles aparentemente intrascendentes en sí mismos; pero que adquieren una función instrumental de gran eficacia al conferirles significaciones implícitas más amplias.

Ante la avalancha de anécdotas que inciden en la confrontación de estereotipos, no son pocos los autores que han caído en la trampa tendida por la memoria oral y los relatos autobiográficos de los divisionarios, aceptando de modo un tanto acrítico aquella autoimagen ciertamente quijotesca y anárquica. Los españoles resultarían ser, así, un contrapunto amable y divertido a la rigidez y crueldad intrínsecamente teutonas. Ello se basaba, como todo estereotipo, en ciertas bases verosímiles. Hay evidencias documentales que prueban la constante incomprensión de los mandos y enlaces alemanes, sobre todo de los situados en la retaguardia, hacia el comportamiento ruidoso, descuidado en las formas, juerguista y poco respetuoso del orden, la limpieza o la higiene de los soldados $y$, lo que les era aún más chocante, de los propios oficiales españoles, cuya afición al vino y la buena comida contrastaba con la prusiana ética militar que imperaba en la Wehrmacht. Y es igualmente cierto que ese contraste era incluso objeto de chanza entre los círculos diplomáticos de los aliados del III Reich ${ }^{64}$. Ejemplos genéricamente semejantes, con todo, también se pueden citar acerca de los soldados de otras nacionalidades combatientes en el frente ruso al lado de los alemanes ${ }^{65}$.

Ese tipismo del relato divisionario tuvo en origen dos posibles y complementarias lecturas. En primer lugar, mostrar las virtudes de la raza hispana al mundo en términos grandilocuentes y retóricos. Como rezaba pomposamente un texto de propaganda falangista de 1943, el "soldado moreno, con olor a claveles y la gloria de sol en las pupilas» habría liegado a Rusia para "fundir sobre el hielo duro de la estepa maldita su sangre caliente de pasiones y de generosidades con la sangre del camarada alemán" en una "comunidad de destino y de ideales, como un día se juntaron las culturas de los dos pueblos en el Emperador de

64. Por poner un ejemplo, vid. Crano, Galeazzo, Diarios 1937-1943, Barcelona, 2003, p. 577.

65. Por ejemplo, rumanos e italianos. Cf. BEEVOR, Anthony, Stalingrad: The Fateful Siege: 1942-1943, Nueva York et al., 1998, pp. 182-84 y 222-30, y Gosztony, Peter, Hitlers Fremde Heere. Das Schicksal der nichtdeutschen Armeen im Ostfeldzug, Düsseldorf/Viena, 1976. 
Europa ${ }^{66}$. Esa retórica propia del estilo poético falangista no perdió en grandilocuencia con los años: en 1954, Juan Eugenio Blanco concluía que «al invierno erizado de balas y de nieve lo derrotó la gracia meridional de Españan ${ }^{67}$. En segundo lugar, se pretendió demostrar asimismo una virtud insospechada de los españoles: su gran capacidad de adaptación a situaciones imprevistas, tanto a la dura disciplina de la Wehrmacht como a las penosas condiciones del frente ruso. Pero esa capacidad no sería nueva, sino una expresión adicional de las cualidades que en siglos pretéritos habían llevado a los españoles a conquistar imperios. El periódico de trinchera de la DA resumía esa visión bien a las claras en marzo de 1942:

La escena de un guripa español conduciendo un trineo, con su abrigo desabrochado y el gorro torcido, es una de las más características en el frente que cubre nuestra División. Parece que no han hecho otra cosa en su vida esos camaradas andaluces que seguramente en su pueblo natal no habían visto nunca un copo de nieve; pero los españoles somos así, en el fin del mundo estamos como en nuestra propia casa. Hoy comprenden los camaradas alemanes de qué manera unos puñados de españoles, perdidos en un continente extensísimo, consiguieron arraigar profundamente su raza, lengua y religión en tierras por completo hostiles [...]. Donde todos fracasan, los españoles, sin entrenamiento de medios, son capaces de realizar auténticos milagros $^{68}$

De hecho, prácticamente todas las memorias y autobiografías, e incluso varios de los documentales fílmicos -hasta los realizados en tiempos recientes ${ }^{69}$-, incluyendo las más profesionales memorias de varios altos oficiales divisionarios $^{70}$, insisten en destacar repetidamente la particular alegría vital de los voluntarios españoles, su tendencia a la anarquía y a la indisciplina, y su afición a las aventuras sentimentales con las mujeres alemanas, polacas, rusas o letonas. Un sinfín de anécdotas recurrentes ilustrarán un topos del relato divisionario: los españoles eran soldados indisciplinados, clara expresión del anárquico espíritu ibérico. Pero en el fragor del combate eran insuperables y asombro de propios y extraños, precisamente por su temperamento pasional. Lo llevarían en la sangre: "De raza somos indisciplinados, envalentonados, sobrios, solidarios, amantes del humilde, caballerosos, protectores de mujeres y niños [...] fieles a la palabra dada, valientes y sumamente orgullosos de nuestro pasado»; pues «en algunos aspectos somos incomparables e incomprensibles. Y ante el peligro [...]

66. Vicesecretaría de Educación Popular, División Azul. $2{ }^{\circ}$ Cuaderno, Madrid, 1943, s/p.

67. Blanco, Juan Eugenio, Rusia no es cuestión de un día, Madrid, 1954, p. 44.

68. "Los transportes en la División Azul", Hoja de Campaña, n. ${ }^{\circ} 19,16.3 .1942$, p. 4.

69. Cf. el documental Die Blaue Division. Die Geschichte der spanischen Kriegsfreiwilligen an der Ostfront, Polar Film 2001. Pero también el de Ruoxo, Javier, Extranjeros de sí mismos, (2001), donde se traza un paralelo implícito entre el idealismo de las Brigadas Internacionales y el de la División Azul.

70. Por ejemplo, el recuento del segundo comandante en jefe de la DA: EstebAn Infantes, Emilio, La División Azul; un enfoque semejante en Diaz de VILLeGAs, José, La División Azul en linea, Barcelona, 1967, y en Martinez Esparza, José, Con la División Azul en Rusia, Madrid, 1943. 
no tenemos que envidiar a nadie ${ }^{71}$. Eso era lo que les llevaría a no ceder un milímetro frente al Ejército Rojo: una suerte de sentimiento trágico de la vida que se traducía en un acusado desprecio de la muerte. Ambas caras de la moneda eran resumidas en 1954 por Tomás Salvador: «A un español se le dice que debe cargar un camión con alambrada o cavar un refugio y dice que vaya su padre; se le dice que tiene que morir y le parece estupendo ${ }^{72}$. La metáfora más recurrente era la que presentaba a los divisionarios como "Quijotes con ametralladoras, hombres enteros, pero sin ninguna disciplina», que estarían "siempre velando las armas con el alto pensamiento en la Dulcinea de nuestros sueños, que es España» ${ }^{73}$. Frente al frío rendimiento bélico del combatiente alemán, que, eso sí, "sabe morir disciplinadamente y comprende lo hondo de su deber en una aclamación racional de los medios al fin inmediato", los españoles combatirían de modo acorde a su instinto secular, en un "coqueteo con la fatalidad" ${ }^{74}$.

Esta autoimagen tuvo al menos otras dos lecturas complementarias. La primera, vigente sobre todo durante la década de los 40 , permitía trocar la frustración de la derrota en victoria simbólica: el general invierno, que sí había derrotado a las tropas de Napoleón, no pudo doblegar el tesón español. Pues la batalla contra el invierno casi polar había sido la más atroz exigencia que tuvieron que superar unos soldados morenos y meridionales ${ }^{75}$. Más adelante surgirá una segunda lectura, convenientemente acrecentada, de ese juego de contraposiciones y estereotipos. Particularmente, cuando será necesario destacar ante la opinión pública, con posterioridad a 1945, que los voluntarios de la DA eran muy diferentes de los soldados de la Wehrmacht. Para ello, autobiografías, novelas y testimonios diversos incidirán en la presentación de esa autoimagen tipista como contraposición implícita frente al soldado alemán. Recurso defensivo del que también harán gala, por ejemplo, los testimonios publicados tras 1945 de combatientes italianos en el frente del Este ${ }^{76}$. El alegre y simpático soldado español, manifestación genuina de un sano ideal, nunca sería capaz de llevar a cabo aquellas atrocidades que, sin embargo, sí podían ser capaces de cometer los fríos alemanes.

Como ya apuntamos, la gran mayoría de la publicística y memorialística divisionaria, con pocas excepciones ${ }^{77}$, apenas menciona temas escabrosos co-

71. Fernández Blanco, Laurentino, op. cit., p. 75; Castañón, José Manuel, op. cit., p. 28.

72. SALVADOR, Tomás, op. cit., p. 334.

73. Ydigoras, Carlos M. a op. cit., p. 302; Castañon, José Manuel, op. cit., p. 45.

74. Nıeto TunCiA, T., "Sangre española en Rusia», Enlace, n. ${ }^{\circ} 14,13.12 .1942$, p. 3.

75. Vid. por ejemplo "La infantería española", Hoja de Campaña, 22, 6.4.1942, p. 4. Era curiosamente una suerte de lectura invertida de la que extraía y difundía la propaganda de guerra soviética, la cual reflejaba las penalidades de los invasores alemanes y sus aliados en el duro invierno de 1941-42 con el fin de demostrar que la invencible maquinaria de la Wehrmacht también era vulnerable. Vid. Hamann, Christoph, "Feindbilder und Bilder vom Feind", en Museum BerlinKARLSHORST (ed.), Beutestücke. Kriegsgefangene in der deutschen und sowjetischen Fotografie 19411945, Berlín, 2003, pp. 16-31.

76. Vid. GosztonY, Peter, op. cit., pp. 263-265.

77. Por ejemplo, Álvarez de Sotomayor Gil de Montes, Manuel, Generación Puente, Alicante, 1991 , p. 173, o Ydícoras, Carlos M. ${ }^{2}$, op. cit., pp. 62-69. 
mo el Holocausto. En la narrativa divisionaria se negará de modo taxativo que los españoles tuviesen conocimiento alguno, mientras estuvieron en el frente o mientras atravesaron Europa, de la persecución de los judíos y de la existencia de campos de concentración, y no digamos de exterminio ${ }^{78}$. Al mismo tiempo, el negacionismo o el revisionismo historiográfico de la Shoah, con los típicos argumentos esgrimidos por quienes pretenden rebajar las dimensiones o incluso negar la existencia de los campos de exterminio -su relativización frente a la existencia de campos de concentración en otros países y regímenes, la supuesta inviabilidad técnica y funcional de las cámaras de gas, la difusión de propaganda aliada y al servicio de Israel, etcétera- también goza de buena acogida entre los antiguos combatientes. Así se aprecia en varias autobiografías más o menos noveladas ${ }^{79}$. Incluso, algunos testimonios publicados a lo largo de la última década del siglo XX todavía mencionan explícitamente la "conspiración judía» como un desencadenante inmediato de la reacción defensiva de Alemania en septiembre de $1939^{80}$. Pero, al mismo tiempo, el relato divisionario intentará mantener una difícil equidistancia entre la simpatía por la causa de los camaradas alemanes y sus victimas judías, polacas o soviéticas. Se admitirá, aunque poniendo en cuestión su dimensión cuantitativa, la existencia del genocidio nazi. Pero se aducirá siempre el manido argumento de la culpa compartida de uno y otro bando. Tanto los soviéticos, desde las fosas de Katyn hasta los Gulags estalinistas, como los aliados, con sus bombardeos masivos sobre las ciudades alemanas y el lanzamiento de sendas bombas atómicas sobre Japón, habrían cometido atrocidades que no los hacían mejores que los germanos ${ }^{81}$. Además, el haber compartido combate y experiencias con soldados alemanes ha creado un vínculo de solidaridad y camaradería más fuerte que cualquier evidencia. Ángel Ruiz Ayúcar resumía así en 1954 su particular concepción de la equidistancia española tanto de soviéticos como de alemanes:

De los campos de concentración se ha hablado mucho en esta triste y rencorosa postguerra. Todo el mundo ha arrojado su piedra sobre el caído, sin mirar primero si sus manos estaban limpias. En esta actitud no se ha quedado atrás el Occidente cristiano. [...] No espere nadie que nosotros nos unamos a esta lapidación. Si tuviéramos que reprochar algún crimen a los alemanes, lo reservaríamos para cuando fueran poderosos y temidos. No nos gusta hacer de cuervos sobre las tumbas ni de dar lanzadas a los moros muertos. [...] Nosotros, que no tenemos nada que pedir ni nada que temer, nos podemos dar el gusto de no insultar. Ni a unos ni a otros. Hemos

78. «Habíamos jurado la bandera alemana y era como si fuéramos de ellos, pero no sabíamos nada de lo que hacían los nazis ni teníamos idea de lo que eran los campos de concentración", afirmaba en el 2003 el canario Enrique Vera Morales Vid. su testimonio en GÁLVEz, Lucía, Historias de inmigración. Testimonios de pasión, amor y arraigo en tierra argentina (1850-1950), Buenos Aires, 2003, pp. 441-51.

79. Un ejemplo paradigmático es MARTínez-MENA, Miguel, Las "batallitas" de mi abuelo, Alicante, 1991 , pp. 36 y $39-42$.

80. EsPinosa POVEDA, Arturo, „iTeniamos razón!! Cuantos luchamos contra el comunismo soviético, Madrid, 1993, p. 67.

81. CASTelo Villaoz, Pablo, URSS: Un rayo de luz y esperanza, Alicante, 1992, pp. 87-88. 
quitado de nuestros relatos de Rusia toda animosidad contra los que fueron nuestros enemigos. No vamos a caer, por dar gusto a las corrientes de moda, en la aberración de ofender a los que fueron nuestros camaradas ${ }^{82}$.

A eso se unía el argumento del desprecio alemán, patente por lo demás en los altos mandos de la Wehrmacht, por el combatiente español, y la supuesta discriminación de la DA por sus aliados. Argumento que permitía convertir a los divisionarios españoles, en la práctica, poco menos que en unas víctimas más del III Reich ${ }^{83}$. Y que se sumaba a la interpretación del envío de la División Azul al frente ruso promovida por el régimen franquista desde 1945: aquélla habría sido una suerte de rehén ofrecido a Hitler para evitar que éste obligase a España a entrar en el conflicto. Pero el valor demostrado por los españoles en Rusia le habría disuadido, incluso, de cruzar los Pirineos...

\section{e) El descubrimiento del uauténtico" pueblo ruso}

Los españoles también habrían sido los únicos combatientes encuadrados en el ejército invasor que habrían comprendido a los rusos, al sencillo pueblo ninguneado y maltratado por los alemanes. Otro elemento omnipresente en la memoria divisionaria hasta el día de hoy, y que contribuyó sobremanera a forjar la leyenda de la División Azul, es la que describe el comportamiento de los soldados españoles con la población rusa como ejemplar, humano y rayano en la confraternización con los ocupados. La complejidad de situaciones que entrañaba la estrecha convivencia de los soldados españoles con la población civil de la línea del frente y la inmediata retaguardia, donde las tropas ocupantes encontraban cobijo en las casas de los campesinos, es por lo general sumamente idealizada en el relato divisionario. En él, la relación con la población civil se reduce a un esquema más simple: la buena vecindad, la simpatía y la cercanía con los campesinos rusos. Lo que, a la postre, se convertiría en uno de los discursos más eficaces para justificar la presencia española en suelo soviético: se trataría de una gran victoria moral de la DA. Como resumía José Antonio Vidal y Gadea en 1991, la conducta de la División en el frente y en retaguardia "fue, sin disputa, ejemplar. Supo conciliar el Valor con el Amor, impregnado todo ello con sentido del Honor ${ }^{84}$. El cuadro que describen las memorias y testimonios de los voluntarios, en conjunto, traza un paisaje de armónica convivencia y hasta de confraternización. No sólo habría existido buena vecindad entre los soldados españoles y los campesinos, sino además pleno respeto, aprecio y hasta solidaridad entre unos y otros. Tanto era así, que los lugareños habrían protegido a sus ocupantes españoles de los partisanos, y poco menos que habrían llorado al partir los españoles. La división española habría constituido un oasis de generosidad y buen trato a la población civil en medio del infierno. Buen trato que se hacía extensivo a los prisioneros del Ejército Rojo que caían en sus manos.

82. Ruiz Ayúcar, Ángel, La Rusia que yo conocí, Madrid, 1981 [1954], p. 156.

83. Por ejemplo, Blanco, Juan Eugenio, op. cit., p. 15.

84. Vidal y Gadea, José Antonio, Op. cit., p. 63. 
Esa visión no sólo es recreada por la publicística pseudohistórica generada sobre y alrededor de los ex-combatientes de la División Azul y de la Wehrmacht en general, sino que también ha impregnado la visión de la experiencia de la División Azul en el frente ruso por más de un historiador ${ }^{85}$. Interpretación que, a la postre, se convertiría en uno de los discursos más eficaces para justificar durante la Guerra Fría la presencia española en suelo soviético: se trataría de una gran victoria moral de la DA, al no haber sido corresponsable ni siquiera indirectamente de la política nazi de exterminio. Tan patente sería aquella verdad, que ni siquiera el régimen estalinista pudo -o quiso- aducir contra la España de Franco un solo ejemplo de represalias masivas contra la población civil. Es más, el repliegue de la DA al llegar el momento de su repatriación en octubre de 1943 habría podido efectuarse sin ser hostigada por la artillería soviética, como recompensa del Ejército Rojo por el buen trato dispensado a los civiles ${ }^{86}$.

En ese relato, sin embargo, están ausentes muchos matices. Desde los frecuentes actos de pillaje perpetrados por los soldados españoles desde su llegada al frente, que causaron la constante preocupación de los propios mandos alemanes, hasta los acosos sexuales a mujeres, pasando por las esporádicas represalias en respuesta a ataques de los partisanos, las ejecuciones sumarias de espías y partisanos, etcétera. Es posible afirmar, y algunos testimonios rusos asílo corroboran, que los ocupantes españoles se caracterizaron por un trato más humano y próximo que el dispensado en general por las tropas alemanas ${ }^{87}$. Pero ello no excluyó ni abusos por parte española ni incidentes varios, particularmente debidos a la propensión de las tropas españolas al pillaje, con la población civil, según recogian incluso los informes del Ejército alemán. Por otro lado, la imagen de Rusia, sus habitantes y los propios combatientes del Ejército soviético que los combatientes españoles llevaron consigo, y que desarrollaron durante su estancia en el frente, no correspondía a una Weltanschauung impregnada de racismo biológico y eliminatorio. Sin embargo, los testimonios coetáneos no dejan de mostrar que el falangismo divisionario no dejaba de considerar que el pueblo ruso era cultural y espiritualmente inferior, una víctima propicia de la barbarie comunista por su carácter asiático y abotargado. Un racismo cultural, en definitiva, que, eso sí, dejaba abierta la puerta a la posibilidad de la conversión de Rusia una vez que ésta se liberase del comunismo, particularmente mediante

85. Caso, en mi opinión, de Bowen, Wayne, "A Great Moral Victory", o de KreInfelD, Gerald R., y TAmbs, Lewis A., op. cit. Pero también, aunque de modo más matizado, de Moreno Juliá, Xavier, op. cit.

86. Pérez Caballero, Ramón, Vivencias y recuetdos: Rusia, 1941-1943, Madrid, 1986, p. 12; Blanco, Juan Eugenio, op. cit., pp. 37-38; Garcia LunA, José, op. cit., pp. 56-58 y 234-237, o De ANDRÉS Y Andrés, Antonio, Artilleria en la División Azul (Krasny Bor), Madrid, 2004, p. 140.

87. Por ejemplo, el diario de Lidia Ósipova, civil residente en Pávlovsk, entre el 25 de agosto y el 5 de octubre de 1942, reproducido en LomaGuin, Nikita, Neizvéstnaya blocada (documenti, prilozhéniya), San Petersburgo, 2004 [2." ed.], vol. 2, pp. 464-472. 
la reintroducción del culto religioso ${ }^{88}$. Conversión que, de hecho, muchos excombatientes de la DA creyeron ver llegada tras 1989.

\section{f) ¡Teniamos razón! La conversión de Rusia}

La narrativa divisionaria mantuvo incólume la convicción de que, a pesar de todo, el comunismo era el gran enemigo. Incluso aquellos veteranos que más tarde, como Dionisio Ridruejo, el abogado y escritor asturiano José Manuel Castañón o el también escritor Luis Romero, evolucionaron hacia posturas democráticas, mantuvieron que los voluntarios de 1941 no se habrían equivocado en su decisión. La División Azul sería una muestra del idealismo más sano que era capaz de generar la juventud falangista todavía en estado puro y revolucionario, no contaminada por las actividades represivas del régimen franquista y su claudicación frente a la plutocracia conservadora y la Iglesia católica ${ }^{89}$.

El ideal anticomunista de 1936-39 y de 1941 se habría visto reforzado, además, por la constatación de la pobreza y miseria del campesinado ruso y el atraso material del país, que incluso habría hecho mella en voluntarios que procedían de familias de izquierda, y reafirmaba a los voluntarios en su orgullo por haber derrotado al adversario en España en $1939^{90}$. Esas experiencias valían a más de un veterano de la DA a principios de la década de 1950, como el coronel Díaz de Villegas, para impartir «seminarios de formación» a las jerarquias provinciales de FET sobre los efectos del comunismo en Rusia ${ }^{91}$. En semejantes términos incidieron los testimonios de los prisioneros retornados en 1954, al rememorar sus contactos y conversaciones con sus vigilantes o con la población civil en algunos campos de trabajo de la URSS: la miseria de las gentes, que pasarían tanta o más hambre y necesidades que los presos y que a menudo congeniaban con éstos cuando eran destinados a ayudar en labores agricolas, sería ya sólo una consecuencia de la crueldad del sistema soviético y de su trato inhumano a sus propios ciudadanos, de la sistemática destrucción de los vínculos

88. Cf. para más detalles Núñez SerXas, Xosé Manoel, «¿Eran los rusos culpables? Imagen del enemigo y políticas de ocupación de la División Azul en el frente del Este, 1941-1944", artículo inédito (2005).

89. Vid. RIDruejo, Dionisio, Con fuego y con raices. Casi unas memorias, Barcelona, 1976, pp. 332-334.

90. Caso del voluntario malagueño Rafael Castaño Doña, nacido en 1925, quien había vivido la guerra civil con su familia en Málaga, la huida de las tropas italianas y el exilio por un breve tiempo en un campo de refugiados francés, y dos de cuyos hermanos habían combatido en milicias obreras, sufriendo represión por ello tras 1939. Sin embargo, Castaño se enrola en la DA por afán de aventura y por la paga en 1943, y se presenta voluntario para la Legión Azul al retirarse aquélla del frente en octubre de ese año "tal vez debido a mi espíritu aventurero", pero también, según su confesión, porque "yo ya había conocido las consecuencias del comunismo en mi tierra. Y lo que había hecho el comunismo con las pobres gentes rusas». Vid. CASTAÑo DoÑA, Rafael, op. cit., p. 80. Vid. también las impresiones del estudiante de Derecho y después abogado, nacido en 1919, SÁnCHez CARRILero, Javier, op. cit., pp. 15-17.

91. Vid. Diaz de Viliegas, José, Lo que vi en Rusia, Madrid, 1950; del mismo autor, Rusia por dentro, Madrid, 1951. Igualmente, GARCiA LunA, José, op. cit., pp. 38-39 y 121. 
familiares y de las tradiciones religiosas por parte del comunismo $0^{92}$. La pobreza del pueblo ruso, provocada por la esclavitud comunista y las falsas promesas de la revolución bolchevique, se doblaba de una inmensa miseria espiritual, hasta llegar a «la más espantosa depravación moral», que en algunos casos, como en la caricatura del comunista soviético que recreaba J. L. Vascano, llegaría a desear «el amor libre, [...] la mujer como un instrumento de producción al servicio del proletariado"; o que, en las crónicas del voluntario albaceteño Javier Sánchez Carrilero, habría desnaturalizado tanto la vida cotidiana del pueblo ruso que habría eliminado «el cariño de la madre hacia sus hijos»"

No sólo la Guerra Fría habría confirmado la determinación de los voluntarios de la DA en señalar como el principal enemigo de la civilización occidental, de la cultura europea y, sobre todo, de los valores cristianos al comunismo soviético. Un enemigo que continuaba siéndolo, y que seguía manteniendo a sus habitantes en la miseria, según corroboraban con fruición los escasos relatos de viajes de retorno de antiguos divisionarios a la URSS con anterioridad a $1989^{94}$. La caída del muro de Berlín y la reunificación de Alemania en 1990, primero ${ }^{95}$, y de modo casi inmediato la definitiva conversión de Rusia y del resto de países de Europa Oriental, dejando atrás por sí solos el comunismo a partir de 1989, vendría a incidir involuntariamente en la misma línea argumental. Teniamos razón quienes luchamos contra el comunismo soviético, se titulará uno de los principales libros de memorias aparecidos en la década de 1990, y que narraba precisamente el retorno de un voluntario falangista y activo miembro de la Hermandad Nacional de la División Azul a Rusia. Una vez caído el comunismo, los antiguos voluntarios, ahora ancianos, se reencontraban con el sencillo y religioso, místico y ferviente pueblo ruso que ya habían conocido en su juventud ${ }^{96}$. Se trataría del triunfo de la Rusia eterna, de la auténtica esencia de un alma y un pueblo que sólo había sido pasajeramente contaminada por la revolución bolchevique. Esencia que únicamente los soldados españoles habían sido capaces de descubrir gracias a su sensibilidad religiosa, a su ausencia de prejuicios raciales y a su desbordante simpatía. Un noble idealismo prototípico de las mejores virtudes hispánicas, en definitiva, y que definía su misión recristianizadora del pueblo ruso como una continuación de la obra iniciada por España en América en 1492... Así se reflejaba muy bien en la casi profética aserción que, en una de las obras ficcionalizadas acerca de su experiencia en la División Azul publicada en 1998 por el coronel Enrique de la Vega, se ponía en boca de un pope ruso que en 1941 podía volver a ejercer su ministerio gracias a los ocupantes españoles:

92. Vid. por ejemplo Puente, Moisés, op. cit., pp. 88-89, 97 y 133-136; OroovieTa Arbiol, Gerardo, y García Sánchez, César, op. cit, pp. 96-97; Poouet Guardiola, op. cit., pp. 28-31.

93. JiMÉnez Andrades, Ildefonso, op. cit., pp. 39 y 51; VAsCano, J. L., op. cit, p. 84; SÁnchez Carrilero, Javier, op. cit, pp. 25-27.

94. Vid. por ejemplo Mas, Vicente, "Dos viajes a Rusia», Blau División, n. ${ }^{\circ} 537$ (abril 2004), pp. 6-8.

95. Vid. el empático testimonio de Castelo VillaOz, Pablo, Otra vez en Grafenwohr, Alicante, 1991, p. 66.

96. Espinosa Poveda, Arturo, op. cit. 
Algún día, Dios sabe cuándo, todo esto acabará... Y se reconstruirá la Rusia eterna, aunque pudiera ser que un poco menos, reducida a lo que fue a comienzos del siglo XVI. [...] Algún día reconstruiremos la Rusia exacta, tal vez más pequeña... que hoy, pero más auténtica. Tenemos un viejo vocablo para designar ese renacer, esa reconstrucción, perestroika, que algún día resucitará97.

Esta premonición sentida por los soldados españoles en Rusia constituiría su victoria final, pese a las incomprensiones del antifranquismo y la uhistoriografía oficial». De ahí que muchos llegasen a la conclusión de que Serrano Súner estaba equivocado. Rusia no habría sido culpable, sino el comunismo soviético, responsable a su vez de que las cualidades del pueblo ruso se hubiesen tornado amenazas para la civilización occidental ${ }^{98}$.

El ciclo de la épica divisionaria se cierra así de modo circular con el retorno de los divisionarios octogenarios a un país liberado del comunismo, y con el reposo eterno de los muertos españoles en cementerios propios, sobre todo si pueden retornar a suelo patrio. Dado que, por razones biológicas evidentes, son pocos ya los testimonios que se siguen publicando y su ritmo decrece, todo parece indicar que el final de la narrativa divisionaria está por llegar próximamente, pese a su demostrada capacidad de autorreproducción. Ahora es el turno de la investigación histórica. Otra cuestión es si la auténtica renovación de la mirada historiográfica sobre la División Azul, sus dimensiones y significado en la historia de las guerras españolas del siglo XX, podrá venir de una historia militar plácidamente instalada en la ignorancia más supina de los vientos de renovación que desde hace más de dos lustros recorren esa disciplina en el contexto historiográfíco europeo, acercándola a las preocupaciones de la Historia social y cultural. Pero ésta es otra historia.

97. De la Vega Viguera, Enrique, op. cit., pp. 33-34; en el mismo sentido, Sánchez Carrilero, Javier, op. cit., pp. 19-21.

98. De la VeGa Viguera, Enrique, Rusia no es culpable. Historia de la División Azul, Madrid, 1999, pp. 9-11; Martínez Espinosa, Remigio, "Prólogo", en Sánchez Carrilero, Javier, op. cit., pp. 7-9. 